Alma Mater Studiorum - Università di Bologna DEPARTMENT OF ECONOMICS

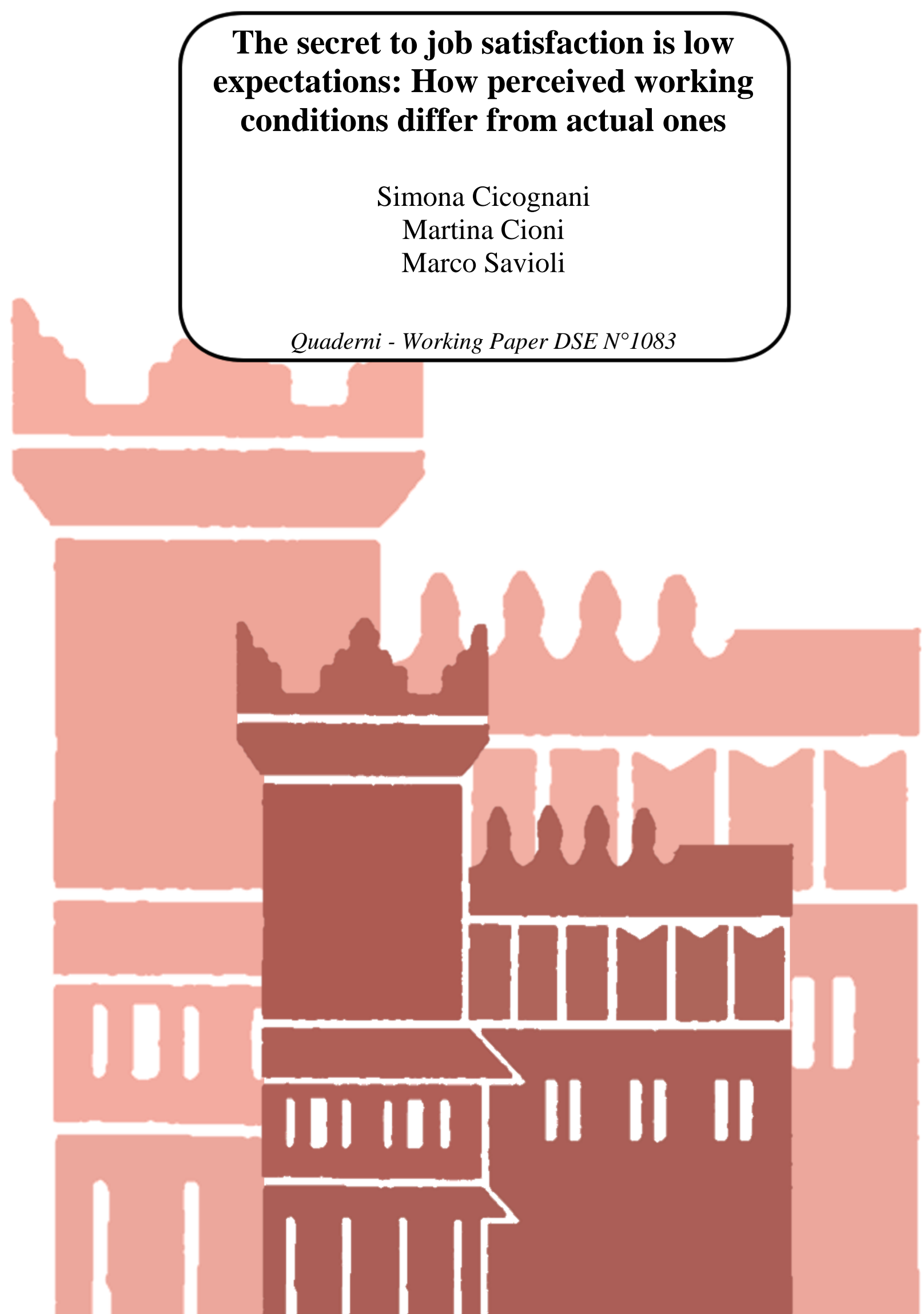




\title{
The secret to job satisfaction is low expectations: How perceived working conditions differ from actual ones
}

\author{
$\underline{\text { Cicognani, Simona }}^{\star \text { Cioni, Martina }}{ }^{\star \quad \text { Savioli,Marco }}{ }^{\star}$
}

\begin{abstract}
Working conditions exert a major influence on accidents and illnesses at work as well as on job satisfaction and health, yet very little research has examined the determinants of working conditions. By exploiting the Italian Labour Force Survey, this paper provides evidence on the underlying factors affecting working conditions. It provides a behavioural interpretation of the results, which stems from the discrepancy between actual and expected working conditions. In light of this interpretation, workers would declare their perceived working conditions influenced by the difference between the actual and the expected working conditions. Variables concerning personal characteristics, such as gender, education and being employed in the first job, shift expectations about working conditions and accordingly perceived working conditions. On the contrary, variables related to work characteristics, such as working full time, with shifts and in a large place, affect actual and thus perceived working conditions (negatively).
\end{abstract}

Keywords: working conditions, expectations, perceptions, actual conditions, job satisfaction

JEL classification: D84, J24, J28

PsycINFO classification: $3670,3650,3040$

Acknowledgements: We thank Tiziano Arduini, Alessandro Bucciol, Tiziano Razzolini and seminar participants at the Department of Economics, University of Bologna. The usual disclaimers apply.

- Department of Economics, University of Verona, Italy and RCEA, Rimini, Italy, simona.cicognani@univr.it

• Department of Economics and Statistics, University of Siena, Italy, cionimart@ unisi.it

^ Department of Economics, University of Bologna, Italy and RCEA, Rimini, Italy, m.savioli@unibo.it 


\section{Introduction}

In the past decades, labour economics research has demonstrated the influence of working conditions on a number of issues, such as the probability of experiencing job accidents and illnesses in the workplace as well as workers' job satisfaction, health and quality of life more generally. For instance, a recent article on work safety by Cioni and Savioli (2016) highlights that poor working conditions are among the major determinants of accidents and illnesses at work.

Despite the sizeable empirical literature that provides insights into and evidence on working conditions as factors influencing the aforementioned issues, no work so far investigates the determinants of working conditions, hence treating working conditions as a dependent variable. The only exception is the research by Askenazy and Caroli (2010), who study the impact of new work practices and ICT on a number of indicators of working conditions, which are considered as separate dependent variables. Their results show that new practices are related to higher mental strain and that ICT tends to reduce injuries in the workplace. Working conditions are usually treated as independent variables that affect different dependent variables, ranging from self-assessed health or psychological well-being (Loscocco and Spitze, 1990; Robone et al., 2011) to work safety (Cioni and Savioli, 2016) or wages (Hersch, 1991; Poggi, 2007; Fernandez and Nordman, 2009). Understanding the factors that determine working conditions may lead to better-targeted public policies, which also affect important issues such as work accidents/illnesses, health and quality of life, all of which are strictly connected to the productivity of work (Alavinia et al., 2009; Fink and Masiye, 2015).

This paper seeks to fill this gap in the literature by investigating the determinants of working conditions and providing the first theoretical modelization and empirical validation of workers' 
perceptions of working conditions. To do so, we focus on Italy, a considerable country of the European Union in terms of both GDP and population, using data from the 2007 Italian Labour Force Survey. In this specific year, the survey contained a special ad hoc section on working conditions, in which workers were asked to state whether they faced risk factors. Accordingly, our argumentations will be presented in terms of poor working conditions and the results will simply be read in the opposite direction to reflect the literature about working conditions. Having data from 2007 allows us to investigate the pre-crisis labour dynamics, which were not affected by workers' worsened perceptions of working conditions due to the Italian recession that started in 2008. The contribution of the paper is twofold: we explain the role of working conditions by analysing their determinants and we provide a behavioural explanation of how working conditions can be perceived by workers.

A clear definition of working conditions is still lacking in the literature, since very different concepts are used interchangeably across the various contributions. Robone et al. (2011) consider as working conditions promotion and annual wage increment opportunities as well as having a managerial/supervision role, working outside regular office hours and being subject to unpaid overtime. Other studies, such as those by Hersch (1991) and Askenazy and Caroli (2010), also take into account mental strain factors, occupational risks (e.g. risk of a serious fall, electricity risk, etc.) and occupational injuries. More in line with the latter contributions, we use a broad concept of working conditions, encompassing both physical and psychological risk factors, which are selfassessed by workers.

In several studies working conditions are measured using self-reported answers. This is not necessarily a negative trait, considering that, according to many ergonomics experts, working 
conditions cannot be defined independently of workers' characteristics (Burchell et al., 2009). Indeed, working conditions are affected by personal and cultural features as well as by objective working conditions (Eurofound, 2012). Based on this reasoning, the actual (objective) working conditions and the expectations regarding them may present a discrepancy (Poggi, 2010). This discrepancy originates the perceived working conditions, which are those declared by individuals and captured in the survey. Following this argument, the main hypothesis of this paper is that the same actual working conditions can be perceived differently by workers according to their personal characteristics. We envisage the personal characteristics of the worker, such as gender, education and being employed in the first job, as affecting mainly her expectations of working conditions. On the contrary, work characteristics, such as working full time, with shifts or in a large place, are deemed to exert an impact mainly on the actual working conditions of the worker.

A somewhat related concept to working conditions is job satisfaction, which is usually selfmeasured by workers on a Likert scale. A recent report on working conditions highlights that job satisfaction varies across employment status, educational attainment, occupation and sector, with skilled agricultural workers, plant and machine operators and workers in elementary occupations being the least satisfied with their jobs (Eurofound, 2012). The existing contributions in the literature on job satisfaction show that age and job satisfaction are characterized by a U-shaped relationship, with very young and very old workers being the most satisfied with work (Clark et al., 1996; Clark, 1997). Working conditions refer to specific sub-categories of the working environment and can therefore be conceived as the determinants of job satisfaction. Indeed, several contributions in the medical and psychological literature reveal that job stress, arising from working conditions, is associated with job dissatisfaction and negative mental well-being (Cooper et al., 1989; Travers and Cooper, 1993). Job satisfaction is the part of overall life satisfaction that can be ascribed to work 
and represents an important factor for understanding individuals' well-being (Dolan et al., 2008). Consequently, we consider job satisfaction as the separable part of an individual's utility stemming from work, as is common practice in the literature on life satisfaction (Clark and Etilé, 2011).

Our findings indicate that variables concerning the work characteristics working full time, overtime, with shifts and in a large place negatively affect the actual working conditions. The remaining variables, concerning personal characteristics, determine the expected working conditions influencing the perception of the actual working conditions.

The paper is organized as follows. Section 2 presents the theoretical specification. Section 3 describes the data set used and provides some descriptive statistics. Section 4 reports the methodology adopted in the empirical analysis and the results. Finally, Section 5 concludes with a discussion of the results.

\section{Theoretical background}

Variables that are unambiguously related to actual work characteristics, such as the sector of activity, the level of occupation, the size of the establishment and working full time, with shifts or with overtime hours are considered to affect working conditions through the actual channel (Muñoz de Bustillo and Fernández-Macías, 2005). Once the actual characteristics of the work environment are controlled for, we assume that the personal characteristics of the individual exert their effect through the expected working conditions. For instance, once we have controlled for the specific work to be undertaken, we deem having a fixed-term contract to be a variable that acts on expectations: working with a contract characterized by a specific expiration date is likely to influence the personal psychological sphere of the worker and therefore his or her expectations. This is a crucial point, considering that, given the changes in the labour market that have occurred, 
especially in the last two decades, a significant portion of contracts have switched from standard, open-ended, full-employment contracts to fixed-term contracts, part-time contracts and unregulated work (Barbieri and Scherer, 2009).

The underlying assumption of this paper is that declared (perceived) working conditions are not a direct translation of actual working conditions but are strongly influenced by workers' expectations. For some of the regressors, in addition to actual working conditions, we can envisage an expectation dimension that should be accounted for and stems from the reference point theory of Kahneman and Tversky (1979) and the disappointment theory of Bell (1985), that was tested by Van Dijk et al. (2003).

As postulated by Bell (1985), two consequences with the same outcome can accrue different utility levels if we consider the actual outcome compared with the prior expectations. This is the case for instance of winning a certain monetary prize in a lottery and knowing that it is the top prize as opposed to knowing that it is the lowest prize available. In the two cases, the utility perceived will be different, since in the former case we would be delighted whereas in the latter we would be disappointed.

The reference point is explicitly considered as the agent's recent expectations about the relevant outcomes by Kőszegi and Rabin (2006), who model expectations as rational expectations. In this case the agent's utility function is composed of two terms: a consumption utility term, which reflects the classical outcome-based utility, and a gain-loss utility term, which is the difference between the consumption utility and the reference point. Since the reference point is determined by rational expectations, it follows that it is determined endogenously by the economic environment characterizing the agent's recent past. 
The same line of reasoning can be applied in the context of working conditions, in which expectations about working conditions interplay with actual working conditions. In this respect the seminal work of Clark (1997) is the first to propose a central role played by expectations in shaping workers' job satisfaction, focusing on the so-called "gender-job satisfaction paradox": women face on average worse working conditions than men but report higher job satisfaction levels than their male counterparts. ${ }^{1}$ The explanation provided by Clark is based on the well-being of workers related to their job expectations. From this perspective, since women are often secondary earners and highly involved in home production and since their working conditions are generally worse than men's, they hold lower expectations towards their job than men. This explanation is supported by the fact that women who are supposedly characterized by higher expectations (such as those in managerial positions or with mothers in a professional job) do not report a higher level of job satisfaction with respect to their male colleagues. According to Clark's hypothesis, as soon as women are emancipated, the gender-job satisfaction gap will decrease. This hypothesis is empirically tested by Sousa-Poza and Sousa-Poza (2010) on 10 waves of the British Household Panel Survey (1991-2000). The gender-job satisfaction paradox appears to be transitory, as the data suggest that it has halved over the decade, driven primarily by a decline in women's job satisfaction. Furthermore, Helliwell and Huang (2011) highlight some gender differences in the ways in which male and female workers evaluate their workplaces, for instance in terms of trust in the management (higher for women). Similarly, a strand of literature explains that some less advantaged workers have higher satisfaction levels than workers with demonstrably better actual working conditions if the latter workers have higher expectations about their job (Muñoz de Bustillo et al., 2011; Burchell et al., 2014).

\footnotetext{
${ }^{1}$ See also Zaleznik et al. (1958).
} 
Following Muñoz de Bustillo and Fernández-Macías (2005), ${ }^{2}$ we assume that all the variables relating to workers' personal characteristics exert an influence on their expectations of working conditions. Education is certainly among these: we believe that a higher education level allows the worker to approach her job with higher expectations regarding working conditions or makes the worker aware of the long-term consequences of bad working conditions. This thesis is supported by Clark (1997), who finds gender differences in job satisfaction for middle and low-educated individuals in favour of women, whereas highly educated women do not report different job satisfaction from men: hence, it seems that more educated women have higher expectations, more similar to those of men, than less educated women. Therefore, job satisfaction declines with the level of education (see also Clark and Oswald, 1996 and Sloane and Williams, 2000). In addition, being in the first job can affect expectations about working conditions, lowering them and hence improving the perceived working conditions. Indeed, the agent's recent expectations about the relevant outcomes determine a different reference point for workers in their first job (Köszegi and Rabin, 2006). Long job tenure, on the other hand, provides workers with capital of experience that allows them to have a more robust perception of the working conditions. Regarding age, Schwandt (2016) shows that well-being (life satisfaction) follows a U-shape over age by means of expectations. In our case, even though a higher age may make working loads seem heavier and hence worsen perceived working conditions, it may also engender experience, which helps to provide a more precise perception of working conditions (Burchell et al., 2009).

We envisage two context variables that can be ascribed to the personal sphere of the worker as important drivers of expectations of working conditions: the unemployment rate and the unionization index at the regional level. The expectations in this case originate in relation to a local

\footnotetext{
${ }^{2}$ According to Muñoz de Bustillo and Fernández-Macías (2005, p. 664), indicators of job expectations encompass age, sex, education and experience of unemployment.
} 
context, characterized by reference groups. For instance, the higher the unionization index, the greater the awareness of workers' rights and consequently the higher the expectations of working conditions. In this case the expectations would spread through the social context. According to Cahill et al. (2015, p. 40):

... the information individuals glean about the economic context may shape attitudes and intentions, such as job and career satisfaction, career plans, turnover intentions, retirement intentions, psychological well-being and assessments of work-life balance.

They highlight the role of macroeconomic conditions, such as the unemployment rate, in influencing workers' job satisfaction and expectations. To sum up, a clear distinction of the variables involved in the empirical analysis between the variables driving the actual working conditions (work characteristics) and the variables acting on expectations (personal characteristics) is depicted in Table A1 of the Appendix.

\subsection{Theoretical formulation}

It is useful to formalize the preceding arguments with a simple theoretical formulation in which we indicate how the perception of working conditions can result. To be consistent with our empirical estimations, in which workers' statement about whether they face risk factors is employed, we now turn to thinking in terms of bad working conditions. Specifically, we can envisage the individual utility function as:

$$
u[\underbrace{\widetilde{b w c}}_{-}, \underbrace{b w c^{*}}_{+}(\underbrace{f e}_{+}, \underbrace{e d}_{-})]=u[\underbrace{b w c}_{-}]
$$


where - and + indicate the sign of partial derivatives and $u$ stands for utility, $\widetilde{b w} c$ for actual bad working conditions, $b w c^{*}$ for expected bad working conditions and $b w c$ for perceived bad working conditions; $f e$ and $e d$, indicating respectively being female and the amount of acquired education, are two illustrative independent variables affecting expectations with opposite signs. On the righthand side of Eq. (1), the utility function is expressed in terms of perceived bad working conditions, $b w c$, which are captured by the survey responses. In line with Köszegi and Rabin (2006), who model a gain-loss utility term as the difference between the consumption utility and the reference point, we can assume that perceived bad working conditions are given by the difference between actual, $\widetilde{b w} c$, and expected, $b w c^{*}$, bad working conditions. The latter are assumed to be a function of variables related to personal characteristics, such as being female and education, which shift expectations of bad working conditions upwards and downwards, respectively. Note that the concavity/convexity of the utility function around the reference point is not an issue inasmuch as the function is monotone in its arguments. What is important is that the signs of the first-order partial derivatives do not change along the utility function.

Agents' utilities are latent and cannot be observed. The same applies to actual bad working conditions. However, following the utility function of Eq. (1), the perceived (and declared) bad working conditions can be expressed as:

$$
b w c[\underbrace{\tilde{b w c}(W, P)-b w c^{*}(\underbrace{f e}_{+}, \underbrace{e d}_{-}, W, P)}_{+}]=f[\underbrace{f e}_{-}, \underbrace{e d}_{+}, W, P]
$$


where $W, P$ are work and personal characteristics; $f[$.$] is a function (which is estimated in Section$ 4); and - and + indicate the sign of the partial derivatives, which are solved on the right-hand side of Eq. (2) and are tested in the estimations.

It is important to recall that in our case utility refers only to job satisfaction and not to other life occurrences. The difference in survey responses represents a real difference in utility from perceived bad working conditions, $b w c$. Nevertheless, the paradox of counterintuitive signs of derivatives is solved by considering the importance of expectations in bad working conditions, $b w c^{*}$. Those who expect higher levels of bad working conditions, like women, will be more satisfied with any given level of actual bad working conditions, $\widetilde{b w c}$ (see Eq. (1)), and will declare lower perceived bad working conditions (see Eq. (2)). The opposite applies to more educated workers.

Expectations may form an important part of the reference level by which utility gains/losses are evaluated, since relative rather than absolute arguments determine utility (job satisfaction). According to Kahneman and Tversky (1979, p. 277):

When we respond to attributes such as brightness, loudness, or temperature, the past and present context of experience defines an adaptation level, or reference point, and stimuli are perceived in relation to this reference point.

Since higher levels of education are associated with less satisfied workers, workers with high ed deem a lower level of bad working conditions, $b w c^{*}$, to be fair. $f e$ workers, on the contrary, have a worse past and present context of work to which they would have adapted and to which they refer (higher $\left.b w c^{*}\right)$. 
Again, since Eq. (1) is not observable, we can only test its validity by measuring and empirically estimating Eq. (2). More specifically, by using data on $b w c, f e, e d, W$ and $P$, we will validate our theoretical predictions with empirical estimations.

\section{Data}

Our analysis is based on data from the Labour Force Survey carried out by Istat, the National Institute of Statistics of Italy. The data set is entirely comparable with those collected in other EU countries. ${ }^{3}$ It refers to the second quarter of 2007, when an "ad hoc" module devoted to safety and health at work was added to the standard information contained in the Istat Labour Force Survey. The 2007 survey collected various kinds of information on workers' personal and work characteristics and especially on bad working conditions. In particular, the "ad hoc" module devoted to safety and health at work includes information on workers' exposure to health risk factors. By considering all these factors as proxies for different aspects of bad working conditions, we define the variable bad working conditions simply as the sum of the dichotomous indicators of exposure to health risk factors. In particular, the seven risk factors considered encompass both physical and psychological factors. The physical risk factors refer to: exposure to dust, fumes or chemicals; exposure to excessive noise or vibration; bad posture induced by work requirements and movement of heavy loads; and exposure to a general risk of injury. The risk factors that refer mainly to the psychological balance of workers include: excessive workload; phenomena of bullying or discrimination; and exposure to threats or physical violence. The data set includes only micro-data of employees with open-ended and fixed-term contracts, excluding individuals with other kinds of labour relations and unemployed individuals. Thereby, the observations have a high

\footnotetext{
${ }^{3}$ Istat collects the information each quarter by interviewing a sample of nearly 77,000 households (approximately 300,000 in one year), representing 175,000 individuals who are Italian residents.
} 
degree of homogeneity and comparability. To enrich the analysis, we added information on the 2007 second-quarter unemployment rate drawn from Istat's "Conti economici regionali" (regional economic accounts), and we computed a unionization index at the regional level as the ratio between the number of employees who are members of one of the three biggest Italian labour union confederations (CGIL, CISL and UIL) and the total employed Italian population. ${ }^{4}$

Table A1 in the Appendix contains a brief description of each variable employed in the analysis. The dependent variable bad working conditions is the sum of the indication of the seven bad working conditions (described above), normalized from zero to one. We divide the explanatory variables into two groups: work and personal characteristics. Among the work characteristics, we consider working time (dummy variables for full-time work, overtime hours and shift work), the size of the place of work (a dummy variable indicating more than ten workers at the place of work) ${ }^{5}$ and the main activity sector of the firm (grouped into the categories agriculture, industry, construction, retail and other activities). Moreover, the specific kind of job performed by the employee is controlled for by eight categories, ranging from executive or intellectual occupations to unskilled occupations. The personal characteristics encompass gender, birthplace (Italy or abroad), age, marital status and type of contract (fixed-term vs. open-ended contract). Among others, and following previous works (Clark and Oswald, 1996; Sloane and Williams, 2000), we consider the following as human capital indicators and hence personal characteristics: months of current job tenure, first job, years of education and recent educational activity. Quadratic terms for the

\footnotetext{
${ }^{4}$ In line with Poggi (2007), we consider as the numerator of the unionization index the sum of employees who are members of the three main union confederations in Italy, thus excluding retired members. This is due to the great variety of retired members across the different confederations, whose membership levels differ to a large extent across Italian regions. As the denominator we use the total employed population to have a more precise measure of the percentage of employed individuals who are affiliated with a union confederation.

${ }^{5}$ Since Italy is characterized by a vast majority of small-medium enterprises, ten workers in a typical place of work is a meaningful threshold that can be considered too small in other industrial economies (see, e.g., Bartelsman et al., 2003).
} 
numerical variables are introduced into the regressions to control for non-linearities in their effects. Finally, the inclusion of the unemployment rate and unionization index allows us to capture specific socio-economic geographical information that can affect workers' reporting of bad working conditions.

The data set contains 42,198 workers. The average worker in the sample is 41 years old, has tenure of about 10 years (138 months) and has completed high school education (12 years of education). Moreover, the vast majority of workers have full-time work (85\%), work in medium-large places (72\% in places of work with more than 10 workers), are not a foreigner (93\%) and are married $(60 \%)$. Only a minority of individuals work overtime hours $(8 \%)$, perform shift work (22\%), have a fixed-term contract (14\%) and have recently participated in educational activities (5\%).

Table 1 reports the summary statistics of the variables used in this analysis. The kernel estimation in Figure 1 presents the distribution of bad working conditions, showing that the majority of workers report no or few bad working conditions.

Table 1 - Descriptive statistics

\begin{tabular}{|c|c|c|c|c|c|}
\hline & Type & Mean & $S D$ & Min & $\operatorname{Max}$ \\
\hline \multicolumn{6}{|l|}{ Independent variables } \\
\hline \multicolumn{6}{|c|}{ Work characteristics } \\
\hline Full-time work & D & 0.85 & 0.35 & 0 & 1 \\
\hline Overtime hours & $\mathrm{D}$ & 0.08 & 0.28 & 0 & 1 \\
\hline Shift work & $\mathrm{D}$ & 0.22 & 0.41 & 0 & 1 \\
\hline Place of work +10 & $\mathrm{D}$ & 0.72 & 0.45 & 0 & 1 \\
\hline Agriculture as the reference category & $\mathrm{D}$ & 0.03 & 0.17 & 0 & 1 \\
\hline Industry excluding construction & $\mathrm{D}$ & 0.24 & 0.43 & 0 & 1 \\
\hline Construction & $\mathrm{D}$ & 0.07 & 0.26 & 0 & 1 \\
\hline Retail & $\mathrm{D}$ & 0.12 & 0.32 & 0 & 1 \\
\hline Other activities & $\mathrm{D}$ & 0.54 & 0.50 & 0 & 1 \\
\hline Executive or entrepreneur as the reference category & $\mathrm{D}$ & 0.02 & 0.14 & 0 & 1 \\
\hline Intellectual or scientific occupation & $\mathrm{D}$ & 0.09 & 0.29 & 0 & 1 \\
\hline Technical position & $\mathrm{D}$ & 0.24 & 0.43 & 0 & 1 \\
\hline Office clerk & $\mathrm{D}$ & 0.12 & 0.33 & 0 & 1 \\
\hline Qualified occupation & $\mathrm{D}$ & 0.15 & 0.36 & 0 & 1 \\
\hline Craftsman, skilled worker or farmer & $\mathrm{D}$ & 0.16 & 0.37 & 0 & 1 \\
\hline Operator of industrial machinery & $\mathrm{D}$ & 0.11 & 0.31 & 0 & 1 \\
\hline Unskilled occupation & $\mathrm{D}$ & 0.10 & 0.30 & 0 & 1 \\
\hline
\end{tabular}




\begin{tabular}{lrrrrr} 
& Type & Mean & SD & Min & Max \\
\hline \multicolumn{1}{c}{ Personal characteristics } & & & & \\
Current job tenure & $\mathrm{N}$ & 137.65 & 123.23 & 0 & 696 \\
First job & $\mathrm{D}$ & 0.30 & 0.46 & 0 & 1 \\
Fixed-term contract & $\mathrm{D}$ & 0.14 & 0.35 & 0 & 1 \\
Fixed-term contract, wanted & $\mathrm{D}$ & 0.01 & 0.11 & 0 & 1 \\
Fixed-term contract, non-wanted & $\mathrm{D}$ & 0.13 & 0.33 & 0 & 1 \\
Female & $\mathrm{D}$ & 0.44 & 0.50 & 0 & 1 \\
Born in Italy & $\mathrm{D}$ & 0.93 & 0.26 & 0 & 1 \\
Years of education & $\mathrm{N}$ & 11.81 & 3.46 & 8 & 18 \\
Educational activities in the last four weeks & $\mathrm{D}$ & 0.05 & 0.22 & 0 & 1 \\
Age & $\mathrm{N}$ & 41.35 & 11.07 & 20 & 60 \\
Unemployment rate & $\mathrm{N}$ & 5.76 & 3.38 & 2.79 & 11.87 \\
Unionisation index & $\mathrm{I}$ & 0.27 & 0.05 & 0.21 & 0.42 \\
Never married as the reference category & $\mathrm{D}$ & 0.32 & 0.47 & 0 & 1 \\
$\quad$ Married & $\mathrm{D}$ & 0.60 & 0.49 & 0 & 1 \\
Separated or divorced & $\mathrm{D}$ & 0.06 & 0.24 & 0 & 1 \\
Widow/widower & $\mathrm{D}$ & 0.02 & 0.13 & 0 & 1 \\
\hline Dependent variables & & & & & \\
\hline Bad working conditions & $\mathrm{I}$ & 0.13 & 0.19 & 0 & 1 \\
Exposure to dust, fumes, chemicals & $\mathrm{D}$ & 0.16 & 0.37 & 0 & 1 \\
Noisy workplace & $\mathrm{D}$ & 0.15 & 0.36 & 0 & 1 \\
Bad posture induced by work & $\mathrm{D}$ & 0.20 & 0.40 & 0 & 1 \\
Feeling exposed to risk of injury & $\mathrm{D}$ & 0.22 & 0.41 & 0 & 1 \\
Bad physical working conditions & $\mathrm{I}$ & 0.18 & 0.28 & 0 & 1 \\
Excessive workload & $\mathrm{D}$ & 0.14 & 0.35 & 0 & 1 \\
Feeling exposed to bullying or discrimination & $\mathrm{D}$ & 0.05 & 0.22 & 0 & 1 \\
Feeling exposed to threats or physical violence & $\mathrm{D}$ & 0.02 & 0.12 & 0 & 1 \\
Bad psychological working conditions & $\mathrm{I}$ & 0.07 & 0.16 & 0 & 1 \\
\hline
\end{tabular}

Note. Type: D dummy variable, $\mathrm{N}$ numerical variable, I index variable; SD standard deviation;

The number of observations is equal to 42,198;

Data sources: 2007 Istat Labour Force Survey; “Conti economici regionali”, Istat.

Interesting information comes from the analysis of the geographical distribution of bad working conditions (Figure 2). In particular, workers in northern regions report, on average, lower levels of bad working conditions than southern regions. Since the economic development in Italy increases with latitude to a large extent, ${ }^{6}$ lower actual bad working conditions should be increasingly met moving north. An explanation of the complex plot of (perceived) bad working conditions shown in Figure 2 could additionally hinge on expectations.

\footnotetext{
${ }^{6}$ See, for instance, Felice (2013) and Felice and Vasta (2015) on education and on the delay of the modernization process from the long-run perspective.
} 
Figure 1 -Distribution of bad working conditions

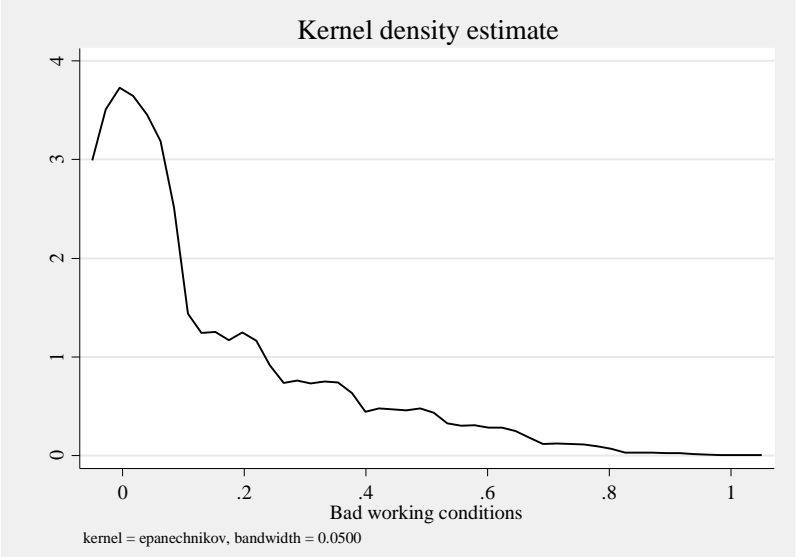

Figure 2 - Regional distribution of bad working conditions

\section{Bad working conditions}

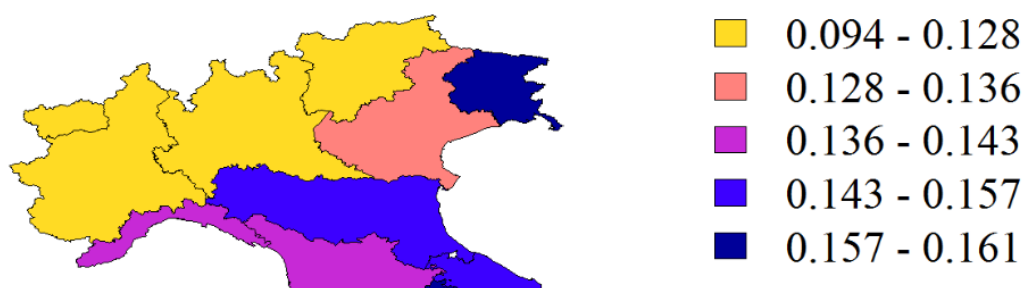

Note. The quintiles of regional averages are shown. Higher bad working conditions are declared, on average, in darker shadowed regions. 
If we assume expectations of increasingly lower levels of bad working conditions moving south, due for instance to a lower level of participation of women in the labour market and a higher level of the unionization index, the difference between actual and expected bad working conditions would reach its maximum in the south of Italy, where actual bad working conditions are higher and expectations are lower than in the north.

\section{Methodology and results}

Perceived bad working conditions are determined by a multiplicity of factors. The actual determinants and expectations intertwine and contribute to workers' final perception of bad working conditions. To uncover the main factors determining working conditions, we first present the regression results of the composite index of bad working conditions that was illustrated in Section 3. Second, the non-linear effects of numerical variables are displayed and discussed. We then provide the conditional marginal effects of some interaction terms. Finally, we divide physical from psychological bad working conditions and break down the composite index of bad working conditions into its individual components, for which we report individual probit regression models to control for the heterogeneity of the main predictors of such a broad concept as bad working conditions.

Eq. (3) is the empirical counterpart of Eq. (2) and is estimated in the following:

$$
b w c=f\left[\alpha+\beta_{W}^{\prime} W+\beta_{P}^{\prime} P+\varepsilon\right]
$$

where $b w c$ are declared bad working conditions; $f[$.$] is a link function; \alpha$ is the constant; $\beta_{W}^{\prime}$ and $\beta_{P}^{\prime}$ are the vectors of coefficients; $W$ is the vector of work characteristics assumed to predict actual 
$b w c ; P$ is the vector of personal characteristics assumed to predict expected $b w c$; and $\varepsilon$ is the error term.

Table 2 reports the estimated coefficients of the models in which the dependent variable is bad working conditions: the main model specification (column 1), a model that controls for a wanted/non-wanted fixed-term contract (column 2) and a model that includes significant interactions (column 3 ). ${ }^{7}$ Since the dependent variable is a unitary index constrained between 0 and 1, we estimate generalized linear models with a logit link and the binomial family (Papke and Wooldridge, 1996). In addition, we compute robust standard errors (Huber/White/Sandwich variance-covariance estimator), which are useful in the case of misspecification of the distribution family and residual heteroskedasticity.

We first comment on model (1) of Table 2, which is the main model specification. The estimates show that full-time workers report higher levels of bad working conditions with respect to part-time workers. In addition, working overtime hours and carrying out work that entails shifts increase the perceived bad working conditions. Clearly, expanding the working time and working difficult hours, ceteris paribus, increase the seriousness of bad working conditions. Working in a place with more than ten employees increases the reported bad working conditions. Consistent with the fact that arduous work exhausts workers' resilience to a larger extent, workers in industry (except construction) and retail report lower levels of bad working conditions than workers in agriculture. Considering the professional status, as expected, executives and entrepreneurs report the lowest bad working conditions with respect to other categories of workers.

\footnotetext{
${ }^{7}$ Other interactions were tested but did not result as significant (the results are available on request).
} 
Table 2 - Bad working conditions - GLM binomial link logit

\begin{tabular}{|c|c|c|c|}
\hline Bad working conditions & $\begin{array}{l}\text { Coefficient } \\
\text { (Rob. st. error) }\end{array}$ & $\begin{array}{l}\text { Coefficient } \\
\text { (Rob. st. error) }\end{array}$ & $\begin{array}{l}\text { Coefficient } \\
\text { (Rob. st. error) }\end{array}$ \\
\hline & $(1)$ & $(2)$ & $(3)$ \\
\hline \multicolumn{4}{|c|}{ Work characteristics } \\
\hline Full-time work & $\begin{array}{c}0.297^{* * *} \\
(0.029)\end{array}$ & $\begin{array}{l}0.295^{* * *} \\
(0.029)\end{array}$ & $\begin{array}{l}0.294^{* * *} \\
(0.029)\end{array}$ \\
\hline Overtime hours & $\begin{array}{l}0.457^{* * *} \\
(0.025)\end{array}$ & $\begin{array}{l}0.456^{* * *} \\
(0.025)\end{array}$ & $\begin{array}{l}0.456^{* * *} \\
(0.025)\end{array}$ \\
\hline Shift work & $\begin{array}{l}0.639^{* * * *} \\
(0.019)\end{array}$ & $\begin{array}{l}0.639^{* * * *} \\
(0.019)\end{array}$ & $\begin{array}{l}0.638^{* * * *} \\
(0.019)\end{array}$ \\
\hline Place of work +10 & $\begin{array}{l}0.126^{* * *} \\
(0.020)\end{array}$ & $\begin{array}{l}0.124^{* * *} \\
(0.020)\end{array}$ & $\begin{array}{l}0.126^{* * *} \\
(0.020)\end{array}$ \\
\hline Agriculture as the reference category & $X^{2}(4)=397.37^{* * *}$ & $X^{2}(4)=398.16^{* * *}$ & $X^{2}(4)=389.54^{* * *}$ \\
\hline Industry excluding construction & $\begin{array}{l}-0.102^{* *} \\
(0.046)\end{array}$ & $\begin{array}{l}-0.104^{*} \\
(0.046)\end{array}$ & $\begin{array}{l}-0.093^{* *} \\
(0.047)\end{array}$ \\
\hline Construction & $\begin{array}{l}0.390^{* * *} \\
(0.049)\end{array}$ & $\begin{array}{l}0.389^{* * *} \\
(0.049)\end{array}$ & $\begin{array}{l}0.392^{* * *} \\
(0.049)\end{array}$ \\
\hline Retail & $\begin{array}{c}-0.258^{* * *} \\
(0.051)\end{array}$ & $\begin{array}{c}-0.259^{* * *} \\
(0.051)\end{array}$ & $\begin{array}{c}-0.249^{* * *} \\
(0.051)\end{array}$ \\
\hline Other activities & $\begin{array}{c}-0.159^{* * *} \\
(0.045)\end{array}$ & $\begin{array}{c}-0.160^{* * *} \\
(0.045)\end{array}$ & $\begin{array}{c}-0.152^{* * *} \\
(0.046)\end{array}$ \\
\hline Executive or entrepreneur as the reference category & $X^{2}(7)=1,214.06^{* * *}$ & $X^{2}(7)=1,211.57^{* * *}$ & $X^{2}(7)=1,211.49^{* * *}$ \\
\hline Intellectual or scientific occupation & $\begin{array}{l}0.214^{* * *} \\
(0.073)\end{array}$ & $\begin{array}{l}0.208^{\text {*** }} \\
(0.073)\end{array}$ & $\begin{array}{l}0.212^{* * *} \\
(0.072)\end{array}$ \\
\hline Technical position & $\begin{array}{l}0.367^{* * *} \\
(0.070)\end{array}$ & $\begin{array}{l}0.361^{* * *} \\
(0.070)\end{array}$ & $\begin{array}{l}0.359^{* * *} \\
(0.070)\end{array}$ \\
\hline Office clerk & $\begin{array}{l}0.231^{* * *} \\
(0.074)\end{array}$ & $\begin{array}{l}0.225^{* * *} \\
(0.074)\end{array}$ & $\begin{array}{l}0.228^{* * *} \\
(0.074)\end{array}$ \\
\hline Qualified occupation & $\begin{array}{l}0.569^{* * *} \\
(0.073)\end{array}$ & $\begin{array}{l}0.564^{* * *} \\
(0.073)\end{array}$ & $\begin{array}{l}0.567^{* * *} \\
(0.073)\end{array}$ \\
\hline Craftsman, skilled worker or farmer & $\begin{array}{l}1.179^{* * *} \\
(0.072)\end{array}$ & $\begin{array}{l}1.173^{* * *} \\
(0.072)\end{array}$ & $\begin{array}{l}1.175^{* * *} \\
(0.072)\end{array}$ \\
\hline Operator of industrial machinery & $\begin{array}{l}1.098^{* * *} \\
(0.073)\end{array}$ & $\begin{array}{l}1.092^{* * *} \\
(0.073)\end{array}$ & $\begin{array}{l}1.094^{* * *} \\
(0.073)\end{array}$ \\
\hline Unskilled occupation & $\begin{array}{l}0.870^{* * *} \\
(0.074)\end{array}$ & $\begin{array}{l}0.864^{* * *} \\
(0.074)\end{array}$ & $\begin{array}{l}0.866^{* * *} \\
(0.074)\end{array}$ \\
\hline \multicolumn{4}{|c|}{ Personal characteristics } \\
\hline Current job tenure & $\begin{array}{l}1.50 \mathrm{e}-03^{*} \\
(2.36 \mathrm{e}-04)\end{array}$ & $\begin{array}{l}1.51 \mathrm{e}-03^{* * *} \\
(2.36 \mathrm{e}-04)\end{array}$ & $\begin{array}{l}1.45 \mathrm{e}-03^{* *} \\
(2.36 \mathrm{e}-04)\end{array}$ \\
\hline Square of current job tenure & $\begin{array}{c}-2.28 \mathrm{e}-06^{* * *} \\
(5.66 \mathrm{e}-07)\end{array}$ & $\begin{array}{c}-2.32 \mathrm{e}-06^{\text {*** }} \\
(5.66 \mathrm{e}-07)\end{array}$ & $\begin{array}{c}-2.21 \mathrm{e}-06^{* * *} \\
(5.66 \mathrm{e}-07)\end{array}$ \\
\hline First job & $\begin{array}{c}-0.170^{* * *} \\
(0.021)\end{array}$ & $\begin{array}{c}-0.169^{* * *} \\
(0.021)\end{array}$ & $\begin{array}{l}-0.170^{\text {**** }} \\
(0.021)\end{array}$ \\
\hline Fixed-term contract & $\begin{array}{l}-0.101^{* * *} \\
(0.027)\end{array}$ & & $\begin{array}{c}0.247^{* * *} \\
(0.096)\end{array}$ \\
\hline Fixed-term contract, wanted & & $\begin{array}{c}-0.409^{* * *} \\
(0.089)\end{array}$ & \\
\hline Fixed-term contract, non-wanted & & $\begin{array}{c}-0.076^{* * *} \\
(0.028)\end{array}$ & \\
\hline Fixed-term contract $*$ Female & & & $\begin{array}{l}-0.091^{*} \\
(0.050)\end{array}$ \\
\hline Female & $\begin{array}{c}-0.253^{* * *} \\
(0.019)\end{array}$ & $\begin{array}{c}-0.254^{* * *} \\
(0.019)\end{array}$ & $\begin{array}{c}-0.264^{* * *} \\
(0.021)\end{array}$ \\
\hline
\end{tabular}




\begin{tabular}{|c|c|c|c|}
\hline Bad working conditions & $\begin{array}{c}\text { Coefficient } \\
\text { (Rob. st. error) }\end{array}$ & $\begin{array}{c}\text { Coefficient } \\
\text { (Rob. st. error) }\end{array}$ & $\begin{array}{c}\text { Coefficient } \\
\text { (Rob. st. error) }\end{array}$ \\
\hline Female $*$ Educational activities in the last four weeks & & & $\begin{array}{l}0.315^{* *} \\
(0.064)\end{array}$ \\
\hline Born in Italy & $\begin{array}{l}-0.128^{* * *} \\
(0.029)\end{array}$ & $\begin{array}{l}-0.125^{\text {*** }} \\
(0.029)\end{array}$ & $\begin{array}{l}-0.129^{\text {*** }} \\
(0.029)\end{array}$ \\
\hline Years of education & $\begin{array}{c}-0.110^{* * * *} \\
(0.019)\end{array}$ & $\begin{array}{l}-0.110^{\text {*** }} \\
(0.019)\end{array}$ & $\begin{array}{l}-0.107^{\text {*** }} \\
(0.019)\end{array}$ \\
\hline Years of education * Fixed-term contract & & & $\begin{array}{c}-0.023^{* * *} \\
(0.007)\end{array}$ \\
\hline Square of years of education & $\begin{array}{l}0.004^{* * *} \\
(0.001)\end{array}$ & $\begin{array}{l}0.004^{* * *} \\
(0.001)\end{array}$ & $\begin{array}{l}0.004^{* * *} \\
(0.001)\end{array}$ \\
\hline Educational activities in the last four weeks & $\begin{array}{l}0.566^{* * *} \\
(0.033)\end{array}$ & $\begin{array}{l}0.566^{* * *} \\
(0.033)\end{array}$ & $\begin{array}{l}0.412^{* * *} \\
(0.047)\end{array}$ \\
\hline Age & $\begin{array}{l}0.020^{* * *} \\
(0.006)\end{array}$ & $\begin{array}{l}0.019^{* * *} \\
(0.006)\end{array}$ & $\begin{array}{l}0.022^{* * *} \\
(0.006)\end{array}$ \\
\hline Square of age & $\begin{array}{l}-2.57 \mathrm{e}-04^{* * *} \\
(6.47 \mathrm{e}-05)\end{array}$ & $\begin{array}{l}-2.49 \mathrm{e}-04^{* * *} \\
(6.47 \mathrm{e}-05)\end{array}$ & $\begin{array}{l}-2.82 \mathrm{e}-04^{* * *} \\
(6.53 \mathrm{e}-05)\end{array}$ \\
\hline Unemployment rate & $\begin{array}{l}0.075^{\text {*** }} \\
(0.019)\end{array}$ & $\begin{array}{c}0.074^{* * *} \\
(0.019)\end{array}$ & $\begin{array}{l}0.074^{* * *} \\
(0.019)\end{array}$ \\
\hline Square of unemployment rate & $\begin{array}{l}-0.006^{* * *} \\
(0.001)\end{array}$ & $\begin{array}{c}-0.006^{* * *} \\
(0.001)\end{array}$ & $\begin{array}{l}-0.006^{\text {*** }} \\
(0.001)\end{array}$ \\
\hline Unionisation index & $\begin{array}{l}1.924^{* * *} \\
(0.217)\end{array}$ & $\begin{array}{l}1.925^{\text {*** }} \\
(0.217)\end{array}$ & $\begin{array}{l}1.929^{* * *} \\
(0.217)\end{array}$ \\
\hline Never married as the reference category & $X^{2}(3)=39.21^{* * *}$ & $X^{2}(3)=39.08^{* * *}$ & $X^{2}(6)=43.58^{* * * *}$ \\
\hline Married & $\begin{array}{l}0.094^{* * *} \\
(0.022)\end{array}$ & $\begin{array}{l}0.094^{* * *} \\
(0.022)\end{array}$ & $\begin{array}{l}0.106^{* * *} \\
(0.023)\end{array}$ \\
\hline Married $*$ Fixed-term contract & & & $\begin{array}{l}-0.110^{* *} \\
(0.054)\end{array}$ \\
\hline Separated or divorced & $\begin{array}{l}0.224^{* * *} \\
(0.037)\end{array}$ & $\begin{array}{l}0.223^{* * *} \\
(0.037)\end{array}$ & $\begin{array}{l}0.234^{* * *} \\
(0.039)\end{array}$ \\
\hline Separated or divorced $*$ Fixed-term contract & & & $\begin{array}{l}-0.111 \\
(0.113)\end{array}$ \\
\hline Widow/widower & $\begin{array}{l}0.120^{*} \\
(0.067)\end{array}$ & $\begin{array}{l}0.119^{*} \\
(0.067)\end{array}$ & $\begin{array}{l}0.147^{* *} \\
(0.070)\end{array}$ \\
\hline Widow/widower * Fixed-term contract & & & $\begin{array}{l}-0.235 \\
(0.226)\end{array}$ \\
\hline Constant & $\begin{array}{c}-3.353^{* * *} \\
(0.194)\end{array}$ & $\begin{array}{c}-3.331^{\text {***k }} \\
(0.194)\end{array}$ & $\begin{array}{c}-3.430^{* * *} \\
(0.195)\end{array}$ \\
\hline $\begin{array}{l}\text { Number of observations } \\
\text { Akaike information criterion } \\
\text { Bayesian information criterion }\end{array}$ & $\begin{array}{c}42,198 \\
0.583876 \\
-438,077\end{array}$ & $\begin{array}{c}42,198 \\
0.583900 \\
-437,966\end{array}$ & $\begin{array}{c}42,198 \\
0.583868 \\
-438,025\end{array}$ \\
\hline
\end{tabular}

Note. Methodology: generalised linear models with a logit link and the binomial family;

Significance levels: ${ }^{*} p<0.10,{ }^{* *} p<0.05,{ }^{* * *} p<0.01$;

When $X^{2}(-)$ is reported instead of coefficient and standard error, the joint significance of the battery of dummy variables is tested;

Data sources: 2007 Istat Labour Force Survey; “Conti economici regionali”, Istat.

The coefficients of first job and female follow the predictions outlined in the theoretical background section: being in the first job and being a woman may be associated with higher expectations about bad working conditions, and this is reflected in lower reported bad working conditions. The same negative coefficient applies to having a fixed-term contract. 
Two variables represent education in the data set: years of education and educational activities in the last four weeks. While the former reflects a very general, long-term and heterogeneous kind of education, the latter is very specific, short-term, recent and more homogeneous among workers in the same job. When we consider the dummy variable for educational activities in the last four weeks, the positive and significant coefficient is in line with the conjectures regarding expectations. Finally, never-married individuals report the lowest levels of bad working conditions compared with married, separated and widowed workers. By examining the magnitude of the coefficients, we note that separated or divorced individuals report the highest levels of bad working conditions.

A concern about the endogeneity of the variable current job tenure may arise, since jobs associated with higher bad working conditions may be more likely to be dropped, resulting in shorter tenures. To control for this issue, we rerun the main model using again generalized linear models with a logit link and the binomial family but also with instrumental variables and the maximum quasilikelihood methodology. As an instrument we use three variables, both together and in separate regressions: (1) a dummy variable signalling whether the worker had ever been in contact with a public employment centre; (2) the number of months from the last time that the individual had contact with a public employment centre; and (3) the number of persons living in the individual's home. All of these variables are meant to capture a higher/lower level of easiness for the individual to change work, which we assume to be exogenous to the level of bad working conditions. All the regressions, available on request, confirm the presented results.

The four panels of Figure 3, relating to model (1) of Table 2, are obtained by computing the prediction and the confidence intervals of bad working conditions for the average individual in the sample for each level of the numerical variables current job tenure, years of education, age and 
unemployment rate, respectively.

Figure 3 - Effects of numerical variables on bad working conditions: current job tenure, years of education, age and unemployment rate

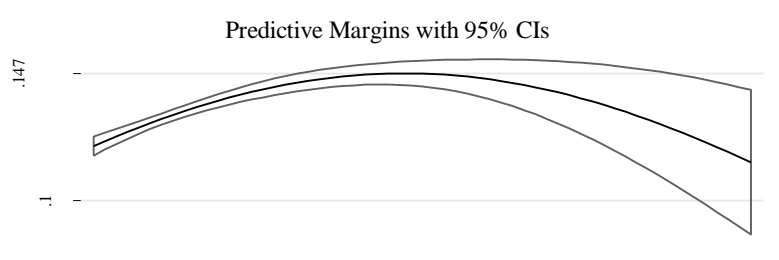

Predictive Margins with 95\% CIs

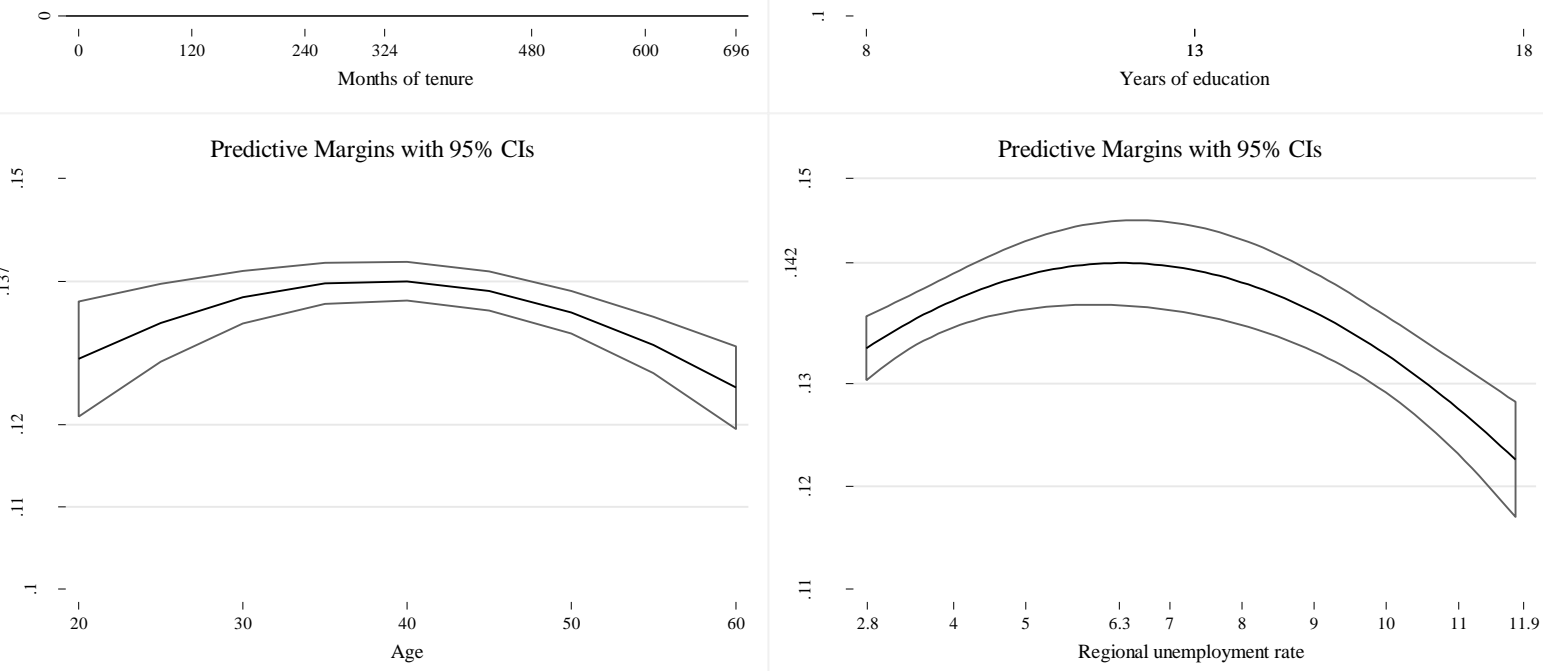

As we can see in the first panel of Figure 3, bad working conditions are predicted to increase as the current job tenure rises until 324 months (27 years), the point at which they reach the maximum. After the peak, they are predicted to decrease. Therefore, we do not find confirmation of the results of García-Serrano (2004), which indicate that temporary workers with short job tenure are associated with jobs with poorer working conditions.

The non-linear trend of years of education is shown in the second panel of Figure 3, with the highest level of bad working conditions being reported by workers at the extremes of the education 
range. This result mirrors what we expected just for the very educated workers, for whom lower expectations about bad working conditions were supposed to translate into higher levels of perceived bad working conditions. On the contrary, workers with the minimum level of education attained reported the highest level of bad working conditions supposedly because of actual worse jobs.

The inverse U-shaped relationship between bad working conditions and age (Figure 3, third panel) highlights that very young and old workers report the lowest level of bad working conditions in the data set.

It is apparent from the fourth panel in Figure 3 that regional unemployment has contrasting effects: it increases both actual bad working conditions and their expectations. For low values of the unemployment rate, the first effect prevails. After a certain threshold level (6.3\% in our estimations) and for a larger interval, the expectation effect prevails, decreasing the perception of bad working conditions. $^{8}$

To corroborate the hypothesis of the wedge between actual and expected working conditions, model (2) of Table 2 controls for wanted/non-wanted fixed-term contracts. More specifically, the variable fixed-term contract wanted indicates a worker who has a fixed-term contract and declares him- or herself to aspire to this specific work arrangement. Conversely, fixed-term contract non-wanted indicates a worker with a fixed-term contract who declares that he or she would prefer a permanent contract. It is clear in this case that the two types of individuals differ only in terms of aspirations. Interestingly, workers with a fixed-term contract who aspired to it exhibit significantly lower levels

\footnotetext{
${ }^{8}$ The average effect of the regional unemployment rate is overall negative, since the predictive margin falls to a lower level on the right side of the figure. This represents the rationale for including this variable among the variables driving expected and not actual bad working conditions.
} 
of bad working conditions.

We conclude the comments on Table 2 by concentrating on model (3), which includes significant interaction terms. The preceding results are mainly confirmed. ${ }^{9}$ To understand the effect of the interacted variables better, we compute the conditional marginal effects presented in Table 3 , which refer to model (3) of Table 2. The average marginal effects are conditional on the categories reported in parentheses. The marginal effects of a fixed-term contract for different genders confirm the negative overall sign for this variable. It is interesting, however, to note that the negative effect of a fixed-term contract is almost double for females. Table 3 also confirms the thesis supported by Clark (1997) as regards the effect of education: the gender differential in job satisfaction in favour of women vanishes for highly educated individuals. Our results show that females stop reporting lower levels of bad working conditions with respect to males once they take part in educational activities in the month preceding the survey interview. Table 3 , in addition, points out the stronger negative effect of education on bad working conditions for workers with a fixed-term contract. Highly educated individuals seem to be less prone to complaining about bad working conditions, especially if their job has a shorter expected duration. Finally, the marital status dummies allow us to ascertain that the temporary workers reporting lower levels of bad working conditions are married.

\footnotetext{
${ }^{9}$ Even though the coefficient of fixed-term contract is significantly positive, interactions with this variable have significant negative coefficients.
} 
Table 3 - Predicted means of bad working conditions - Average marginal effects (conditional)

\begin{tabular}{|c|c|}
\hline Bad working conditions & $\begin{array}{c}\text { dy/dx } \\
\text { (Delta-method st. error) }\end{array}$ \\
\hline Fixed-term contract (Male) & $\begin{array}{l}-0.009^{* *} \\
(0.004)\end{array}$ \\
\hline Fixed-term contract (Female) & $\begin{array}{l}-0.015^{* * *} \\
(0.003)\end{array}$ \\
\hline Female (No Educational activities in the last four weeks) & $\begin{array}{c}-0.029^{* * *} \\
(0.002)\end{array}$ \\
\hline Female (Educational activities in the last four weeks) & $\begin{array}{c}0.006 \\
(0.008)\end{array}$ \\
\hline Years of education (Open-ended contract) & $\begin{array}{c}-1.57 \mathrm{e}-03^{\text {*** }} \\
(4.06 \mathrm{e}-04)\end{array}$ \\
\hline Years of education (Fixed-term contract) & $\begin{array}{c}-3.69 \mathrm{e}-03^{* * *} \\
(7.46 \mathrm{e}-04)\end{array}$ \\
\hline Fixed-term contract (Never married) & $\begin{array}{l}-0.004 \\
(0.004)\end{array}$ \\
\hline Fixed-term contract (Married) & $\begin{array}{l}-0.015^{* * *} \\
(0.004)\end{array}$ \\
\hline Fixed-term contract (Separated or divorced) & $\begin{array}{l}-0.017 \\
(0.012)\end{array}$ \\
\hline Fixed-term contract (Widow/widower) & $\begin{array}{l}-0.026 \\
(0.018)\end{array}$ \\
\hline Number of observations & 42,198 \\
\hline
\end{tabular}

Note. Changes in prediction refer to model (3) of Table 2;

$\mathrm{dy} / \mathrm{dx}$ for the dummy variables Fixed-term contract and Female is the discrete change from the base level;

$\mathrm{dy} / \mathrm{dx}$ for the numerical variable Years of education is the marginal effect;

Significance levels: ${ }^{*} p<0.10,{ }^{* *} p<0.05,{ }^{* * *} p<0.01$;

Data sources: 2007 Istat Labour Force Survey; "Conti economici regionali”, Istat.

The composite index of bad working conditions can be divided into physical and psychological bad working conditions. Furthermore, all its single components can be investigated individually to control for the heterogeneity of the predictors among all the components. Table 4 reports generalized linear models (Papke and Wooldridge, 1996) for physical and psychological bad working conditions and individual probit regression models for each specific component of bad working conditions. Since the dependent variables in the latter case are dummy variables, we estimate probit models by assuming that each latent working condition is deemed (and observed) to be bad whenever it is perceived above a certain threshold. As before, we compute robust standard errors (Huber/White/Sandwich variance-covariance estimator) that are useful in the case of some types of misspecification so long as the observations are independent (Greene, 2007). 
Table 4-Bad working conditions - individual probit and GLM binomial link logit

\begin{tabular}{|c|c|c|c|c|c|c|c|c|c|}
\hline Bad working conditions & $\begin{array}{c}\text { Exposure } \\
\text { to } \\
\text { dust, fumes, } \\
\text { chemicals }\end{array}$ & $\begin{array}{c}\text { Noisy } \\
\text { workplace }\end{array}$ & $\begin{array}{c}\text { Bad } \\
\text { posture }\end{array}$ & $\begin{array}{c}\text { Risk } \\
\text { of } \\
\text { injury }\end{array}$ & $\begin{array}{l}\text { Bad physical working } \\
\text { conditions }\end{array}$ & $\begin{array}{l}\text { Excessive } \\
\text { workload }\end{array}$ & $\begin{array}{c}\text { Bullying } \\
\text { or } \\
\text { discrimination }\end{array}$ & $\begin{array}{l}\text { Threats or } \\
\text { physical } \\
\text { violence }\end{array}$ & $\begin{array}{l}\text { Bad psychological } \\
\text { working conditions }\end{array}$ \\
\hline & $\begin{array}{l}\text { Coefficient } \\
\text { (Rob. st. err.) }\end{array}$ & $\begin{array}{l}\text { Coefficient } \\
\text { (Rob. st. err.) }\end{array}$ & $\begin{array}{l}\text { Coefficient } \\
\text { (Rob. st. err.) }\end{array}$ & $\begin{array}{l}\text { Coefficient } \\
\text { (Rob. st. err.) }\end{array}$ & $\begin{array}{l}\text { Coefficient } \\
\text { (Rob. st. err.) }\end{array}$ & $\begin{array}{l}\text { Coefficient } \\
\text { (Rob. st. err.) }\end{array}$ & $\begin{array}{l}\text { Coefficient } \\
\text { (Rob. st. err.) }\end{array}$ & $\begin{array}{l}\text { Coefficient } \\
\text { (Rob. st. err.) }\end{array}$ & $\begin{array}{l}\text { Coefficient } \\
\text { (Rob. st. err.) }\end{array}$ \\
\hline \multicolumn{10}{|c|}{ Work characteristics } \\
\hline Full-time work & $\begin{array}{l}0.106 \\
(0.028)\end{array}$ & $\begin{array}{l}0.195^{* \ldots} \\
(0.031)\end{array}$ & $\begin{array}{l}0.130^{*} \\
(0.024)\end{array}$ & $\begin{array}{l}0.136^{\text {* }} \\
(0.025)\end{array}$ & $\begin{array}{l}0.248 \\
(0.032)\end{array}$ & $\begin{array}{l}0.335^{*} \\
(0.028)\end{array}$ & $\begin{array}{l}0.027 \\
(0.034)\end{array}$ & $\begin{array}{l}0.073 \\
(0.056)\end{array}$ & $\begin{array}{l}0.411^{-1 *} \\
(0.046)\end{array}$ \\
\hline Overtime hours & $\begin{array}{l}0.229^{* * *} \\
(0.026)\end{array}$ & $\begin{array}{l}0.221^{* * * *} \\
(0.027)\end{array}$ & $\begin{array}{l}0.207^{* * *} \\
(0.026)\end{array}$ & $\begin{array}{l}0.246^{* * * *} \\
(0.025)\end{array}$ & $\begin{array}{l}0.394^{* * * *} \\
(0.031)\end{array}$ & $\begin{array}{l}0.532^{\text {**** }} \\
(0.025)\end{array}$ & $\begin{array}{l}0.243^{* * *} \\
(0.034)\end{array}$ & $\begin{array}{l}0.199^{* * *} \\
(0.052)\end{array}$ & $\begin{array}{l}0.727^{\text {**** }} \\
(0.035)\end{array}$ \\
\hline Shift work & $\begin{array}{l}0.440^{* * *} \\
(0.019)\end{array}$ & $\begin{array}{l}0.452^{* * *} \\
(0.020)\end{array}$ & $\begin{array}{l}0.356^{* * * *} \\
(0.018)\end{array}$ & $\begin{array}{l}0.488^{* * * *} \\
(0.018)\end{array}$ & $\begin{array}{l}0.735^{* * *} \\
(0.022)\end{array}$ & $\begin{array}{l}0.242^{* * *} \\
(0.019)\end{array}$ & $\begin{array}{l}0.335^{* * * * 6} \\
(0.025)\end{array}$ & $\begin{array}{l}0.413^{* * *} \\
(0.036)\end{array}$ & $\begin{array}{l}0.531^{* * * * *} \\
(0.029)\end{array}$ \\
\hline Place of work +10 & $\begin{array}{l}0.061^{* * *} \\
(0.020)\end{array}$ & $\begin{array}{l}0.099^{* * * *} \\
(0.021)\end{array}$ & $\begin{array}{l}0.079^{* * * *} \\
(0.018)\end{array}$ & $\begin{array}{l}0.095^{* * * *} \\
(0.018)\end{array}$ & $\begin{array}{l}0.133^{* * *} \\
(0.023)\end{array}$ & $\begin{array}{l}0.034^{*} \\
(0.020)\end{array}$ & $\begin{array}{l}0.161^{* * * *} \\
(0.029)\end{array}$ & $\begin{array}{l}0.085^{*} \\
(0.046)\end{array}$ & $\begin{array}{l}0.140^{* * * * * 1} \\
(0.033)\end{array}$ \\
\hline $\begin{array}{l}\text { Agriculture as the reference } \\
\text { category }\end{array}$ & $X^{2}(4)=208.68^{* * *}$ & $X^{2}(4)=528.43^{* * *}$ & $X^{2}(4)=481.53^{* * *}$ & $X^{2}(4)=355.04^{* * *}$ & $X^{2}(4)=461.99^{* * *}$ & $X^{2}(4)=45.87^{* * * *}$ & $X^{2}(4)=30.76^{* * *}$ & $X^{2}(4)=73.02^{* * *}$ & $X^{2}(4)=60.99^{* * *}$ \\
\hline $\begin{array}{l}\text { Industry excluding } \\
\text { construction }\end{array}$ & $\begin{array}{l}0.161^{\text {***; }} \\
(0.048)\end{array}$ & $\begin{array}{l}0.421^{* * * *} \\
(0.053)\end{array}$ & $\begin{array}{l}-0.480^{\text {**** }} \\
(0.043)\end{array}$ & $\begin{array}{l}-0.178^{* * *} \\
(0.045)\end{array}$ & $\begin{array}{l}-0.075 \\
(0.053)\end{array}$ & $\begin{array}{l}-0.203^{\text {**** }} \\
(0.052)\end{array}$ & $\begin{array}{l}0.301^{\text {**** }} \\
(0.098)\end{array}$ & $\begin{array}{l}-0.038 \\
(0.177)\end{array}$ & $\begin{array}{l}-0.160^{*} \\
(0.085)\end{array}$ \\
\hline Construction & $\begin{array}{l}0.283^{\text {**** }} \\
(0.052)\end{array}$ & $\begin{array}{l}0.576^{* * * *} \\
(0.056)\end{array}$ & $\begin{array}{l}0.126^{* * *} \\
(0.046)\end{array}$ & $\begin{array}{l}0.344^{\text {**** }} \\
(0.048)\end{array}$ & $\begin{array}{l}0.506^{* * *} \\
(0.056)\end{array}$ & $\begin{array}{l}-0.024 \\
(0.056)\end{array}$ & $\begin{array}{l}0.320^{* * * *} \\
(0.106)\end{array}$ & $\begin{array}{l}0.115 \\
(0.193)\end{array}$ & $\begin{array}{c}0.091 \\
(0.094)\end{array}$ \\
\hline Retail & $\begin{array}{l}-0.139^{* * *} \\
(0.053)\end{array}$ & $\begin{array}{l}-0.026 \\
(0.059)\end{array}$ & $\begin{array}{l}-0.282^{* * *} \\
(0.046)\end{array}$ & $\begin{array}{l}-0.193^{* * 1} \\
(0.048)\end{array}$ & $\begin{array}{l}-0.295^{\text {*N*3+1 }} \\
(0.057)\end{array}$ & 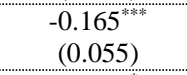 & $\begin{array}{l}0.317^{* * * * 1} \\
(0.102)\end{array}$ & $\begin{array}{l}-0.008 \\
(0.182)\end{array}$ & $\begin{array}{l}-0.120 \\
(0.091)\end{array}$ \\
\hline Other activities & $\begin{array}{l}-0.066 \\
(0.047)\end{array}$ & $\begin{array}{c}0.026 \\
(0.053)\end{array}$ & $\begin{array}{l}-0.347^{* * *} \\
(0.041)\end{array}$ & $\begin{array}{l}-0.102^{\text {***i* }} \\
(0.044)\end{array}$ & $\begin{array}{l}-0.246^{* * *} \\
(0.051)\end{array}$ & $\begin{array}{l}-0.095^{*} \\
(0.050)\end{array}$ & $\begin{array}{l}0.409^{* * *} \\
(0.096)\end{array}$ & $\begin{array}{l}0.353^{* *} \\
(0.173)\end{array}$ & $\begin{array}{c}0.083 \\
(0.082)\end{array}$ \\
\hline $\begin{array}{l}\text { Executive or entrepreneur as } \\
\text { the reference category }\end{array}$ & $X^{2}(7)=917.42^{* * *}$ & $X^{2}(7)=1162.20^{* * * *}$ & $X^{2}(7)=699.03^{* * *}$ & $X^{2}(7)=961.00^{* * *}$ & $X^{2}(7)=1717.67^{* * *}$ & $X^{2}(7)=41.19^{* * *}$ & $X^{2}(7)=9.83$ & $X^{2}(7)=63.20^{* * *}$ & $X^{2}(7)=22.64^{* * *}$ \\
\hline $\begin{array}{l}\text { Intellectual or scientific } \\
\text { occupation }\end{array}$ & $\begin{array}{l}0.491^{* * * *} \\
(0.087)\end{array}$ & $\begin{array}{l}0.379^{* * *} \\
(0.089)\end{array}$ & $\begin{array}{l}0.222^{* * *} \\
(0.081)\end{array}$ & $\begin{array}{l}0.235^{* * *} \\
(0.072)\end{array}$ & $\begin{array}{l}0.623^{* * *} \\
(0.108)\end{array}$ & $\begin{array}{l}-0.287^{* * *} \\
(0.056)\end{array}$ & $\begin{array}{l}0.111 \\
(0.087)\end{array}$ & $\begin{array}{l}-0.077 \\
(0.111)\end{array}$ & $\begin{array}{l}-0.298^{* * *} \\
(0.081)\end{array}$ \\
\hline Technical position & $\begin{array}{l}0.528^{* * *} \\
(0.084)\end{array}$ & $\begin{array}{l}0.428^{* * * *} \\
(0.086)\end{array}$ & $\begin{array}{l}0.479^{* * * *} \\
(0.077)\end{array}$ & $\begin{array}{l}0.395^{* * * *} \\
(0.069)\end{array}$ & $\begin{array}{l}0.896^{* * *} \\
(0.104)\end{array}$ & $\begin{array}{l}-0.272^{* * *} \\
(0.053)\end{array}$ & $\begin{array}{l}0.090 \\
(0.085)\end{array}$ & $\begin{array}{l}-0.171 \\
(0.113)\end{array}$ & $\begin{array}{l}-0.303^{\text {*** }} \\
(0.078)\end{array}$ \\
\hline Office clerk & $\begin{array}{l}0.428^{* * * *} \\
(0.087)\end{array}$ & $\begin{array}{l}0.294^{* * *} \\
(0.089)\end{array}$ & $\begin{array}{l}0.485^{* * *} \\
(0.079)\end{array}$ & $\begin{array}{l}0.195^{* * * *} \\
(0.072)\end{array}$ & $\begin{array}{l}0.699^{* * * *} \\
(0.108)\end{array}$ & $\begin{array}{l}-0.344^{* * * *} \\
(0.056)\end{array}$ & $\begin{array}{l}0.182^{* *} \\
(0.088)\end{array}$ & $\begin{array}{l}-0.023 \\
(0.119)\end{array}$ & $\begin{array}{l}-0.302^{* * *} \\
(0.084)\end{array}$ \\
\hline Qualified occupation & $\begin{array}{l}0.602^{* * *} \\
(0.087)\end{array}$ & $\begin{array}{l}0.351^{* * * *} \\
(0.090)\end{array}$ & $\begin{array}{l}0.707^{* * * *} \\
(0.080)\end{array}$ & $\begin{array}{l}0.663^{* * * *} \\
(0.072)\end{array}$ & $\begin{array}{l}1.182^{* * * *} \\
(0.107)\end{array}$ & $\begin{array}{l}-0.306^{* * *} \\
(0.057)\end{array}$ & $\begin{array}{c}0.084 \\
(0.091)\end{array}$ & $\begin{array}{c}0.136 \\
(0.119)\end{array}$ & $\begin{array}{l}-0.270^{* * *} \\
(0.086)\end{array}$ \\
\hline $\begin{array}{l}\text { Craftsman, skilled worker } \\
\text { or farmer }\end{array}$ & $\begin{array}{l}1.217^{* * \ldots+} \\
(0.086)\end{array}$ & $\begin{array}{l}1.090^{* * *} \\
(0.088)\end{array}$ & $\begin{array}{l}1.059^{* * *} \\
(0.079)\end{array}$ & $\begin{array}{l}1.035^{* * * *} \\
(0.071)\end{array}$ & $\begin{array}{l}2.000^{* * * *} \\
(0.107)\end{array}$ & $\begin{array}{l}-0.299^{* * * * * 1 *} \\
(0.058)\end{array}$ & $\begin{array}{c}0.116 \\
(0.092)\end{array}$ & $\begin{array}{l}-0.212 \\
(0.130)\end{array}$ & 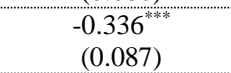 \\
\hline $\begin{array}{l}\text { Operator of industrial } \\
\text { machinery }\end{array}$ & $\begin{array}{l}1.090^{* * * *} \\
(0.087)\end{array}$ & $\begin{array}{l}1.161^{* * *} \\
(0.088)\end{array}$ & $\begin{array}{l}0.912^{* * * *} \\
(0.080)\end{array}$ & $\begin{array}{l}0.977^{* * * *} \\
(0.072)\end{array}$ & $\begin{array}{l}1.899^{* * * *} \\
(0.107)\end{array}$ & $\begin{array}{l}-0.267^{\text {***i* }} \\
(0.059)\end{array}$ & $\begin{array}{c}0.113 \\
(0.092)\end{array}$ & $\begin{array}{l}-0.080 \\
(0.126)\end{array}$ & $\begin{array}{l}-0.268^{* * *} \\
(0.088)\end{array}$ \\
\hline Unskilled occupation & $\begin{array}{l}0.944^{* * * *} \\
(0.088)\end{array}$ & $\begin{array}{l}0.723^{* * *} \\
(0.090)\end{array}$ & $\begin{array}{l}0.963^{* * *} \\
(0.080)\end{array}$ & $\begin{array}{l}0.788^{* * * * *} \\
(0.073)\end{array}$ & $\begin{array}{l}1.630^{* * *} \\
(0.108)\end{array}$ & $\begin{array}{l}-0.324^{* * * *} \\
(0.060)\end{array}$ & $\begin{array}{l}0.115 \\
(0.094) \\
\end{array}$ & $\begin{array}{l}-0.336^{* *} \\
(0.133) \\
\end{array}$ & $\begin{array}{c}-0.388^{* * *} \\
(0.091)\end{array}$ \\
\hline
\end{tabular}




\begin{tabular}{|c|c|c|c|c|c|c|c|c|c|}
\hline Bad working conditions & $\begin{array}{c}\text { Exposure } \\
\text { to } \\
\text { dust, fumes, } \\
\text { chemicals }\end{array}$ & $\begin{array}{c}\text { Noisy } \\
\text { workplace }\end{array}$ & $\begin{array}{c}\text { Bad } \\
\text { posture }\end{array}$ & $\begin{array}{l}\text { Risk } \\
\text { of } \\
\text { injury }\end{array}$ & $\begin{array}{c}\text { Bad physical working } \\
\text { conditions }\end{array}$ & $\begin{array}{l}\text { Excessive } \\
\text { workload }\end{array}$ & $\begin{array}{c}\text { Bullying } \\
\text { or } \\
\text { discrimination }\end{array}$ & $\begin{array}{l}\text { Threats or } \\
\text { physical } \\
\text { violence }\end{array}$ & $\begin{array}{l}\text { Bad psychological } \\
\text { working conditions }\end{array}$ \\
\hline & $\begin{array}{l}\text { Coefficient } \\
\text { (Rob. st. err.) }\end{array}$ & $\begin{array}{l}\text { Coefficient } \\
\text { (Rob. st. err.) }\end{array}$ & $\begin{array}{l}\text { Coefficient } \\
\text { (Rob. st. err.) }\end{array}$ & $\begin{array}{l}\text { Coefficient } \\
\text { (Rob. st. err.) }\end{array}$ & $\begin{array}{l}\text { Coefficient } \\
\text { (Rob. st. err.) }\end{array}$ & $\begin{array}{l}\text { Coefficient } \\
\text { (Rob. st. err.) }\end{array}$ & $\begin{array}{l}\text { Coefficient } \\
\text { (Rob. st. err.) }\end{array}$ & $\begin{array}{l}\text { Coefficient } \\
\text { (Rob. st. err.) }\end{array}$ & $\begin{array}{l}\text { Coefficient } \\
\text { (Rob. st. err.) }\end{array}$ \\
\hline \multicolumn{10}{|c|}{ Personal characteristics } \\
\hline Current job tenure & $\begin{array}{l}1.23 \mathrm{e}-03^{* * *} \\
(2.41 \mathrm{e}-04)\end{array}$ & $\begin{array}{l}9.68 \mathrm{e}-04^{\text {*** }} \\
(2.54 \mathrm{e}-04)\end{array}$ & $\begin{array}{l}6.85 \mathrm{e}-04^{* * *} \\
(2.25 \mathrm{e}-04)\end{array}$ & $\begin{array}{l}6.22 \mathrm{e}-04^{*} \\
(2.26 \mathrm{e}-04)\end{array}$ & $\begin{array}{l}1.34 \mathrm{e}-03^{* *} \\
(2.79 \mathrm{e}-04)\end{array}$ & $\begin{array}{l}9.86 \mathrm{e}-04^{* * *} \\
(2.40 \mathrm{e}-04)\end{array}$ & $\begin{array}{l}1.72 \mathrm{e}-03^{* * *} \\
(3.25 \mathrm{e}-04)\end{array}$ & $\begin{array}{l}1.66 \mathrm{e}-03^{* * *} \\
(5.07 \mathrm{e}-04)\end{array}$ & $\begin{array}{l}2.27 \mathrm{e}-03^{* *} \\
(3.74 \mathrm{e}-04)\end{array}$ \\
\hline Square of current job tenure & $\begin{array}{c}-2.25 \mathrm{e}-06^{* * * *} \\
(5.83 \mathrm{e}-07)\end{array}$ & $\begin{array}{l}-9.30 \mathrm{e}-07 \\
(6.05 \mathrm{e}-07)\end{array}$ & $\begin{array}{l}-1.16 \mathrm{e}-06^{*} \\
(5.44 \mathrm{e}-07)\end{array}$ & $\begin{array}{l}-1.07 \mathrm{e}-06^{*} \\
(5.45 \mathrm{e}-07)\end{array}$ & $\begin{array}{l}-2.11 \mathrm{e}-06^{* * *} \\
(6.71 \mathrm{e}-07)\end{array}$ & $\begin{array}{l}-1.28 \mathrm{e}-06^{*} \\
(5.72 \mathrm{e}-07)\end{array}$ & $\begin{array}{l}-2.99 \mathrm{e}-06^{* * *} \\
(7.70 \mathrm{e}-07)\end{array}$ & $\begin{array}{l}-3.21 \mathrm{e}-06^{* * *} \\
(1.20 \mathrm{e}-06)\end{array}$ & $\begin{array}{l}-3.45 \mathrm{e}-06^{* * *} \\
(8.86 \mathrm{e}-07)\end{array}$ \\
\hline First job & $\begin{array}{l}-0.094^{* * * *} \\
(0.020)\end{array}$ & $\begin{array}{l}-0.128^{* * * *} \\
(0.021)\end{array}$ & $\begin{array}{c}-0.101^{* * *} \\
(0.019)\end{array}$ & $\begin{array}{c}-0.091^{* * *} \\
(0.019)\end{array}$ & $\begin{array}{c}-0.176^{* * *} \\
(0.024)\end{array}$ & $\begin{array}{c}-0.105^{* * *} \\
(0.020)\end{array}$ & $\begin{array}{l}-0.121^{* * *} \\
(0.027)\end{array}$ & $\begin{array}{l}-0.069^{*} \\
(0.040)\end{array}$ & $\begin{array}{l}-0.198^{\text {*w* }} \\
(0.032)\end{array}$ \\
\hline Fixed-term contract & $\begin{array}{l}-0.059^{* * *} \\
(0.027)\end{array}$ & $\begin{array}{l}-2.87 \mathrm{e}-04 \\
(2.85 \mathrm{e}-02)\end{array}$ & $\begin{array}{l}-0.062^{* * *} \\
(0.024)\end{array}$ & $\begin{array}{l}-0.098^{* * *} \\
(0.025)\end{array}$ & $\begin{array}{l}-0.110^{* *-} \\
(0.031)\end{array}$ & $\begin{array}{l}-0.076^{* * *} \\
(0.027)\end{array}$ & $\begin{array}{l}-0.014 \\
(0.037)\end{array}$ & $\begin{array}{l}-0.034 \\
(0.058)\end{array}$ & $\begin{array}{l}-0.112^{* * *} \\
(0.045)\end{array}$ \\
\hline Female & $\begin{array}{l}-0.318^{* * * *} \\
(0.019)\end{array}$ & $\begin{array}{c}-0.293^{* * * *} \\
(0.020)\end{array}$ & $\begin{array}{l}-0.004 \\
(0.017)\end{array}$ & $\begin{array}{l}-0.360^{* * *} \\
(0.017)\end{array}$ & $\begin{array}{c}-0.420^{* * * 6} \\
(0.022)\end{array}$ & $\begin{array}{l}0.057^{* * *} \\
(0.018)\end{array}$ & $\begin{array}{l}0.129^{* * * *} \\
(0.024)\end{array}$ & $\begin{array}{l}-0.066^{*} \\
(0.037)\end{array}$ & 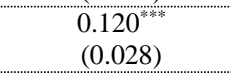 \\
\hline Born in Italy & $\begin{array}{l}0.013 \\
(0.030)\end{array}$ & $\begin{array}{l}-0.046 \\
(0.031)\end{array}$ & $\begin{array}{l}-0.128^{* * *} \\
(0.027)\end{array}$ & $\begin{array}{l}-0.055^{* *} \\
(0.028)\end{array}$ & $\begin{array}{c}-0.095^{* *+4} \\
(0.034)\end{array}$ & $\begin{array}{l}-0.069^{* * *} \\
(0.031)\end{array}$ & $\begin{array}{c}-0.278^{* * * *} \\
(0.039)\end{array}$ & $\begin{array}{c}-0.227^{* * *} \\
(0.061)\end{array}$ & $\begin{array}{l}-0.271^{* * *} \\
(0.049)\end{array}$ \\
\hline Years of education & $\begin{array}{l}-0.068^{* * * *} \\
(0.019)\end{array}$ & $\begin{array}{c}0.010 \\
(0.020)\end{array}$ & $\begin{array}{l}-0.093^{* * *} \\
(0.018)\end{array}$ & $\begin{array}{l}-0.105^{* * *} \\
(0.017)\end{array}$ & $\begin{array}{l}-0.108^{* * *} \\
(0.022)\end{array}$ & $\begin{array}{l}-0.069^{* * * *} \\
(0.018)\end{array}$ & $\begin{array}{c}0.004 \\
(0.024)\end{array}$ & $\begin{array}{l}-0.022 \\
(0.037)\end{array}$ & $\begin{array}{l}-0.072^{* *} \\
(0.028)\end{array}$ \\
\hline Square of years of education & $\begin{array}{l}0.003^{* * * 1 *} \\
(0.001)\end{array}$ & $\begin{array}{l}-0.001 \\
(0.001)\end{array}$ & $\begin{array}{l}0.003^{* * *} \\
(0.001)\end{array}$ & $\begin{array}{l}0.004^{* \text { *** }} \\
(0.001)\end{array}$ & $\begin{array}{l}0.004^{* * *} \\
(0.001)\end{array}$ & $\begin{array}{l}0.003^{* * *} \\
(0.001)\end{array}$ & $\begin{array}{c}1.41 \mathrm{e}-04 \\
(9.61 \mathrm{e}-04)\end{array}$ & $\begin{array}{l}1.53 \mathrm{e}-03 \\
(1.46 \mathrm{e}-03)\end{array}$ & $\begin{array}{l}3.49 \mathrm{e}-03^{\text {**** }} \\
(1.12 \mathrm{e}-03)\end{array}$ \\
\hline $\begin{array}{l}\text { Educational activities in the } \\
\text { last four weeks }\end{array}$ & $\begin{array}{l}0.283^{\text {*** }} \\
(0.035)\end{array}$ & $\begin{array}{l}0.280^{* * * *} \\
(0.037)\end{array}$ & $\begin{array}{l}0.392^{* * * *} \\
(0.032)\end{array}$ & $\begin{array}{l}0.295^{\text {**** }} \\
(0.033)\end{array}$ & $\begin{array}{l}0.563^{* * * *} \\
(0.040)\end{array}$ & $\begin{array}{c}0.365^{* * * *} \\
(0.031)\end{array}$ & $\begin{array}{l}0.327^{* * *} \\
(0.039)\end{array}$ & $\begin{array}{l}0.306^{\text {****7x }} \\
(0.056)\end{array}$ & $\begin{array}{l}0.589^{* * *} \\
(0.044)\end{array}$ \\
\hline Age & $\begin{array}{c}0.002 \\
(0.005)\end{array}$ & $\begin{array}{c}0.009 \\
(0.006)\end{array}$ & $\begin{array}{l}0.013^{* *} \\
(0.005)\end{array}$ & $\begin{array}{l}0.014^{* * *} \\
(0.005)\end{array}$ & $\begin{array}{c}0.018^{* * *} \\
(0.006)\end{array}$ & $\begin{array}{c}0.021^{* * *} \\
(0.006)\end{array}$ & $\begin{array}{l}0.018^{* *} \\
(0.008)\end{array}$ & $\begin{array}{c}0.016 \\
(0.013)\end{array}$ & $\begin{array}{l}0.045^{* * * *} \\
(0.010)\end{array}$ \\
\hline Square of age & $\begin{array}{l}-4.31 \mathrm{e}-05 \\
(6.41 \mathrm{e}-05)\end{array}$ & $\begin{array}{l}-1.22 \mathrm{e}-04^{*} \\
(6.72 \mathrm{e}-05)\end{array}$ & $\begin{array}{l}-1.89 \mathrm{e}-04^{* * *} \\
(5.95 \mathrm{e}-05)\end{array}$ & $\begin{array}{l}-2.07 \mathrm{e}-04^{* * *} \\
(5.99 \mathrm{e}-05)\end{array}$ & $\begin{array}{l}-2.61 \mathrm{e}-04^{* * *} \\
(7.53 \mathrm{e}-05)\end{array}$ & $\begin{array}{l}-2.37 \mathrm{e}-04^{* * *} \\
(6.62 \mathrm{e}-05)\end{array}$ & $\begin{array}{l}-1.67 \mathrm{e}-04^{*} \\
(9.35 \mathrm{e}-05)\end{array}$ & $\begin{array}{l}-1.79 \mathrm{e}-04 \\
(1.50 \mathrm{e}-04)\end{array}$ & $\begin{array}{l}-4.77 \mathrm{e}-04^{* * *} \\
(1.10 \mathrm{e}-04)\end{array}$ \\
\hline Unemployment rate & $\begin{array}{c}0.035^{*} \\
(0.019)\end{array}$ & $\begin{array}{l}0.106^{* * *} \\
(0.020)\end{array}$ & $\begin{array}{l}0.035^{* *} \\
(0.017)\end{array}$ & $\begin{array}{l}0.035^{*} \\
(0.017)\end{array}$ & $\begin{array}{l}0.092^{* * *} \\
(0.022)\end{array}$ & $\begin{array}{l}0.047^{* *} \\
(0.019)\end{array}$ & $\begin{array}{c}0.032 \\
(0.025)\end{array}$ & $\begin{array}{l}-0.059 \\
(0.039)\end{array}$ & $\begin{array}{l}0.055^{*} \\
(0.030)\end{array}$ \\
\hline Square of unemployment rate & $\begin{array}{l}-0.003^{*} \\
(0.001)\end{array}$ & $\begin{array}{c}-0.008^{* * *+} \\
(0.001)\end{array}$ & $\begin{array}{l}-0.003^{* * *} \\
(0.001)\end{array}$ & $\begin{array}{l}-0.003^{* * *} \\
(0.001)\end{array}$ & $\begin{array}{l}-0.008^{* * *} \\
(0.002)\end{array}$ & $\begin{array}{l}-0.003^{* *} \\
(0.001)\end{array}$ & $\begin{array}{l}-0.002 \\
(0.001)\end{array}$ & $\begin{array}{l}0.006^{* *} \\
(0.003)\end{array}$ & $\begin{array}{l}-0.003 \\
(0.002)\end{array}$ \\
\hline Unionisation index & $\begin{array}{l}0.681^{* * * *} \\
(0.222)\end{array}$ & $\begin{array}{l}0.972^{* * *} \\
(0.231)\end{array}$ & $\begin{array}{l}1.502^{* * * *} \\
(0.204)\end{array}$ & $\begin{array}{l}1.724^{* * * *} \\
(0.206)\end{array}$ & $\begin{array}{l}2.134^{* * *} \\
(0.255)\end{array}$ & $\begin{array}{l}1.228^{* * *} \\
(0.219)\end{array}$ & $\begin{array}{l}0.868^{* * * 6} \\
(0.301)\end{array}$ & $\begin{array}{l}-0.547 \\
(0.481)\end{array}$ & $\begin{array}{l}1.668^{* * *} \\
(0.343)\end{array}$ \\
\hline $\begin{array}{l}\text { Never married as the reference } \\
\text { category }\end{array}$ & $X^{2}(3)=9.84^{* *}$ & $X^{2}(3)=12.79^{* * *}$ & $X^{2}(3)=28.23^{* * *}$ & $X^{2}(3)=24.22^{* * *}$ & $X^{2}(3)=33.48^{* * * *}$ & $X^{2}(3)=19.61^{* * * *}$ & $X^{2}(3)=24.38^{* * *}$ & $X^{2}(3)=4.72$ & $X^{2}(3)=27.13^{* * * *}$ \\
\hline Married & $\begin{array}{l}0.057^{* * * * 1 *} \\
(0.021)\end{array}$ & $\begin{array}{l}0.080^{* * * *} \\
(0.023)\end{array}$ & $\begin{array}{l}0.066^{* * * *} \\
(0.020)\end{array}$ & $\begin{array}{l}0.079^{* * * *} \\
(0.020)\end{array}$ & $\begin{array}{l}0.121^{* * *} \\
(0.025)\end{array}$ & $\begin{array}{l}0.058^{* * *} \\
(0.021)\end{array}$ & $\begin{array}{l}-0.026 \\
(0.029)\end{array}$ & $\begin{array}{l}-0.001 \\
(0.046)\end{array}$ & $\begin{array}{c}0.054 \\
(0.035)\end{array}$ \\
\hline Separated or divorced & $\begin{array}{l}0.091^{* *} \\
(0.037)\end{array}$ & $\begin{array}{l}0.083^{* *} \\
(0.040)\end{array}$ & $\begin{array}{l}0.165^{* * *} \\
(0.034)\end{array}$ & $\begin{array}{l}0.149^{* * *} \\
(0.034)\end{array}$ & $\begin{array}{c}0.219^{* * *} \\
(0.043)\end{array}$ & $\begin{array}{c}0.142^{* * *} \\
(0.036)\end{array}$ & $\begin{array}{l}0.158^{\text {*** }} \\
(0.046)\end{array}$ & $\begin{array}{l}0.127^{*} \\
(0.072)\end{array}$ & $\begin{array}{l}0.279^{* * * *} \\
(0.055)\end{array}$ \\
\hline Widow/widower & $\begin{array}{l}-0.010 \\
(0.069)\end{array}$ & $\begin{array}{c}0.062 \\
(0.071)\end{array}$ & $\begin{array}{l}0.158^{* * *} \\
(0.059)\end{array}$ & $\begin{array}{c}0.033 \\
(0.064) \\
\end{array}$ & $\begin{array}{l}0.131^{*} \\
(0.079)\end{array}$ & $\begin{array}{l}0.161^{* * *} \\
(0.061)\end{array}$ & $\begin{array}{l}-0.147^{*} \\
(0.090)\end{array}$ & $\begin{array}{c}-0.085 \\
(0.151)\end{array}$ & $\begin{array}{c}0.094 \\
(0.098)\end{array}$ \\
\hline
\end{tabular}




\begin{tabular}{|c|c|c|c|c|c|c|c|c|c|}
\hline Bad working conditions & $\begin{array}{c}\text { Exposure } \\
\text { to } \\
\text { dust, fumes, } \\
\text { chemicals }\end{array}$ & $\begin{array}{c}\text { Noisy } \\
\text { workplace }\end{array}$ & $\begin{array}{c}\text { Bad } \\
\text { posture }\end{array}$ & $\begin{array}{c}\text { Risk } \\
\text { of } \\
\text { injury }\end{array}$ & $\begin{array}{c}\text { Bad physical working } \\
\text { conditions }\end{array}$ & $\begin{array}{l}\text { Excessive } \\
\text { workload }\end{array}$ & $\begin{array}{c}\text { Bullying } \\
\text { or } \\
\text { discrimination }\end{array}$ & $\begin{array}{l}\text { Threats or } \\
\text { physical } \\
\text { violence }\end{array}$ & $\begin{array}{l}\text { Bad psychological } \\
\text { working conditions }\end{array}$ \\
\hline & $\begin{array}{l}\text { Coefficient } \\
\text { (Rob. st. err.) }\end{array}$ & $\begin{array}{l}\text { Coefficient } \\
\text { (Rob. st. err.) }\end{array}$ & $\begin{array}{l}\text { Coefficient } \\
\text { (Rob. st. err.) }\end{array}$ & $\begin{array}{l}\text { Coefficient } \\
\text { (Rob. st. err.) }\end{array}$ & $\begin{array}{l}\text { Coefficient } \\
\text { (Rob. st. err.) }\end{array}$ & $\begin{array}{l}\text { Coefficient } \\
\text { (Rob. st. err.) }\end{array}$ & $\begin{array}{l}\text { Coefficient } \\
\text { (Rob. st. err.) }\end{array}$ & $\begin{array}{l}\text { Coefficient } \\
\text { (Rob. st. err.) }\end{array}$ & $\begin{array}{l}\text { Coefficient } \\
\text { (Rob. st. err.) }\end{array}$ \\
\hline Constant & $\begin{array}{c}-1.948^{* * *} \\
(0.201)\end{array}$ & $\begin{array}{c}-2.964^{\text {*i* }} \\
(0.210)\end{array}$ & $\begin{array}{c}-1.487^{* * *} \\
(0.183) \\
\end{array}$ & $\begin{array}{l}-1.653^{* * *} \\
(0.182)\end{array}$ & $\begin{array}{c}-3.518^{* * * *} \\
(0.237)\end{array}$ & $\begin{array}{c}-1.748^{* * * *} \\
(0.193) \\
\end{array}$ & $\begin{array}{c}-3.130 * * \\
(0.281) \\
\end{array}$ & $\begin{array}{c}-2.609^{* * * *} \\
(0.430)\end{array}$ & $\begin{array}{c}-4.328^{* * *} \\
(0.311)\end{array}$ \\
\hline Number of observations & 42,198 & 42,198 & 42,198 & 42,198 & 42,198 & 42,198 & 42,198 & 42,198 & 42,198 \\
\hline Pseudo $\mathrm{R}^{2}$ & 0.1292 & 0.1784 & 0.0851 & 0.1298 & --- & 0.0483 & 0.0482 & 0.0904 & --- \\
\hline
\end{tabular}

Note. Methodology: probit regression models and generalised linear models with a logit link and the binomial family;

Significance levels: ${ }^{*} p<0.10,{ }^{* *} p<0.05,{ }^{* * *} p<0.01$;

When $X^{2}(-)$ is reported instead of coefficient and standard error, the joint significance of the battery of dummy variables is tested;

Data sources: 2007 Istat Labour Force Survey; “Conti economici regionali”, Istat. 
Among the work characteristics, the majority of the psychological components of bad working conditions are not significantly affected by full-time work. Furthermore, workers in industry (except construction) have higher levels of bad working conditions in terms of exposure to dust, fumes, chemicals, noisy places and bullying or discrimination. As regards bullying or discrimination, the retail sector also overturns the significant sign, now being positive. While construction is the worst sector in terms of the composite index of bad working conditions, this result does not hold if threats and physical violence are considered individually.

In terms of personal characteristics, the majority of the psychological components of bad working conditions are not significantly affected by having a fixed-term contract as well as noisy workplaces. The effect of the unemployment rate is confirmed mainly for the physical components of bad working conditions, in particular a noisy workplace, bad posture and risk of injury.

It is important to note that women report lower levels of physical bad working conditions and higher levels of psychological bad working conditions with respect to men. To investigate whether this result is driven by lower levels of actual physical bad working conditions faced by women, we focus in more detail on the construction sector, which is typically characterized by severe actual working conditions. We realize that almost the entirety of workers in this sector are male, and especially almost all workers in a craftsman construction occupation are male (99.49 vs. $0.51 \%$ female), meaning that women in the construction sector are employed essentially as clerks. This implies that our categorization among sectors and occupations captures differences in tasks at work, which reflect different actual working conditions. Therefore, the difference in women's perception of physical vs. psychological bad working conditions should be ascribed to the sphere of expectations.

By means of model (1) of Table 2 and the classification of variables driving actual bad working conditions (work characteristics) and variables acting on expectations (personal characteristics), we 
are able to disentangle the two sources of bad working conditions. The panels of Figure 4 represent the regional distribution breakdown of the predictions of bad working conditions, divided into actual and expected bad working conditions. Actual bad working conditions are obtained as predictions by previously fixing all the variables driving expectations (personal characteristics) to sample (national) averages. In so doing, the entire variation is due only to the variables driving actual bad working conditions (work characteristics). The reverse is performed for expected bad working conditions. In the latter case, the sign of the coefficients of the variables driving expectations (personal characteristics) is reversed. The difference between actual and expected bad working conditions (the shadowing in the two panels) composes the predicted (perceived) bad working conditions.

\section{Figure 4 - Regional distribution breakdown of bad working conditions}
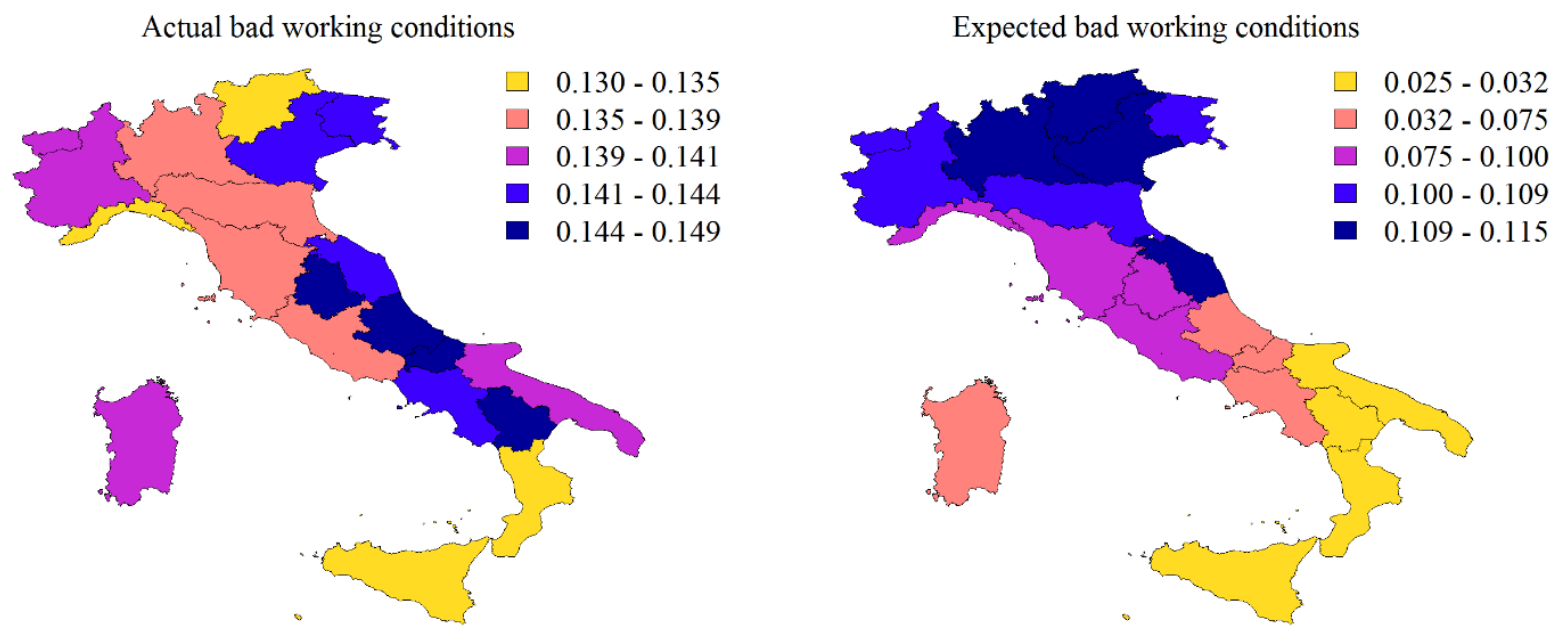

Note. The quintiles of regional averages are shown. Higher bad working conditions correspond, on average, to darker shadowed regions.

The left panel confirms that high levels of actual bad working conditions are present mainly in the central and southern regions of the country, the north of Italy being characterized by more developed and highly technological work environments. The right panel strikingly confirms our 
intuition of increasingly lower levels of expected bad working conditions moving south, due for example to a lower level of women's participation in the labour market and a higher level of the unionization index. It is worth noting that there are differences between actual and expected bad working conditions in all the regions, except Friuli-Venezia Giulia, Calabria and Sicily.

\section{Discussion and conclusion}

In this paper we investigated the determinants of bad working conditions using the 2007 Italian Labour Force Survey, which includes a special ad hoc section on working conditions. We provided a theoretical formulation aiming to explain how working conditions are perceived by workers: in defining the perception of working conditions, actual working conditions are filtered by expectations about them, implying that the same level of actual (real) working conditions can result in different reported (perceived) working conditions. To this end, we applied the behavioural concepts of reference point and disappointment in the field of working conditions.

The results from the regression analyses suggest that the coefficients of the variables ascribed to the expectation sphere of the worker in terms of working conditions are in line with the previous literature contributions, which are mostly based on job satisfaction. The inverse U-shaped relationship between bad working conditions and age mirrors the U-shaped relationship between life satisfaction and age pointed out by Clark et al. (1996) and Schwandt (2016): very young and old workers report the lowest levels of bad working conditions in our data set, and the same consideration holds in terms of job satisfaction in Clark et al.'s (1996) research. Women report lower levels of bad working conditions, which supports the previous findings by Clark et al. (1996) related to job satisfaction. Importantly, through the categorization among sectors and occupations available in our data set, we were able to control for differences in tasks at work, which reflect 
different actual working conditions. Therefore, the difference in women's perception of physical vs. psychological bad working conditions should be ascribed to the sphere of expectations. Interestingly, our results show that Clark's hypothesis could even be overturned: the gender-job satisfaction gap would not vanish but change sign once the increasing share of intellectual work renders the psychological working conditions overwhelmingly more important than the physical working conditions. In fact, we show that, contrary to physical working conditions, women hold lower expected psychological bad working conditions than men. Education also plays an important role in shaping how workers evaluate their working conditions: parallel to the lower job satisfaction for highly educated workers found by Clark (1997), an additional year of education in our data leads to higher levels of bad working conditions, suggesting that more educated workers hold higher expectations. The presence of a variable representing a very short-term educational activity within the workplace, which has the same positive sign as education, corroborates our expectation interpretation. A very recent educational activity that is limited in time cannot have an impact on actual working conditions. Our interpretation is that a shift in expectations takes place: workers who have taken part in (limited) educational activities expect lower levels of bad working conditions than their colleagues who have not attended them.

The result showing that having a fixed-term contract leads to reporting lower levels of bad working conditions with respect to permanent workers deserves much attention. The literature presents mixed evidence in this regard, with some contributions pointing out that workers holding temporary contracts suffer worse working conditions than permanent workers (Benavides, 2000; GarcíaSerrano, 2004) and other contributions showing mixed or opposite results. These mixed or opposite results may be motivated by the lack of complete disentangling of the predictors of actual vs. expected working conditions. For instance, Bernhard-Oettel et al. (2005) underline that health 
complaints are not driven by the type of employment contract but rather by the perception of the job. Furthermore, Bardasi and Francesconi (2004) and Saloniemi (2004) reveal that permanent workers face more high-strain jobs and that atypical employment does not affect health and life satisfaction. Having controlled for the actual determinants of bad working conditions, our result is explained by temporary workers expecting higher levels of bad working conditions than their permanent colleagues. The differential in expectations between the two types of workers results in the negative and significant coefficient. Our expectation interpretation in this case is corroborated by the distinction in terms of bad working conditions between temporary workers who aspired to a temporary contract and temporary workers who would have preferred a permanent contract. Since the two types of individuals differ only in terms of aspirations, the fact that workers with a fixedterm contract who aspired to it exhibit significantly lower levels of bad working conditions should be ascribed to different expectations.

As for marital status, separated or divorced workers report the highest levels of bad working conditions. The fact that married individuals have a lower coefficient than separated workers confirms a well-established finding in the literature: when marital histories worsen, ending up in separation in extreme cases, job satisfaction worsens as well (Rogers and May, 2003; Georgellis et al., 2012). Indeed, divorced individuals experience a loss in utility (job satisfaction) and a corresponding drop in expected (and tolerated) bad working conditions. Interestingly, when marital status is interacted with having a temporary contract, we find that the temporary workers reporting lower levels of bad working conditions are married. An explanation for this could consist of married individuals fearing unemployment spells to a lesser extent, since they find financial and emotional support in their spouse. The bias in the expectation results in a negative surprise in the perceived and declared bad working conditions. 
Workers working full time, overtime or with shifts are likely to report higher levels of bad working conditions as well as workers in a place of work with more than 10 employees. In such cases we consider the actual bad working conditions to mirror the perceived bad working conditions, with no expectation mechanism at work. These results are in line with some theoretical predictions (Khanzode et al., 2012) and some empirical contributions (Cioni and Savioli, 2016) underlining that expanding the working time (such as being a full-time worker, working overtime hours and engaging in shift work), ceteris paribus, increases the chance of accidents and illnesses.

When we examine the individual probit regression models of each component of bad working conditions, the majority of the psychological components of bad working conditions are not significantly affected by full-time work and by having a fixed-term contract. Furthermore, the effect of the unemployment rate holds mainly for the physical components of bad working conditions: a noisy workplace, bad posture and risk of injury.

In a domain afflicted by cognitive biases, policy implications are very likely to fail to be general and are very sensible to the evolving expectations of individuals. As hypothesized by Clark (1997) regarding the decreasing gender-job satisfaction gap over time, the psycho-socio-economic evolution of customs may drastically change expectations. However, our estimations may be useful for policymakers who are willing to consider the psychophysical balance of workers influenced by perceptions and expectations. Moreover, our results show that education and information are key factors able to shift expectations about working conditions (hopefully) closer to the actual ones, diminishing cognitive biases and making workers more self-aware of their actual conditions. In terms of policy recommendations on actual working conditions, our results suggest that workers should not work for an excessive amount of time with difficult hours and should work in small 
places. Lastly, our results on marital status confirm well-known findings in the literature: a more balanced and positive personal life exerts a positive impact on working conditions and consequently on job satisfaction.

One of the most important limitations of this study is the lack of a direct measurement of workers' expectations regarding working conditions. Accordingly, we relied on the previous literature contributions, which suggest a distinction of variables between those affecting primarily actual working conditions and those acting to a larger extent on expectations. Moreover, the data set used did not allow us to track workers within the same establishment and occupation and hence subject to the same objective working conditions. To improve the value of empirical studies, firm-level micro-data would certainly provide a better clue in the direction of an expectation interpretation. With information about organizational charts and salary, it would be possible to grasp the actual working conditions better. The directions for future research should encompass the elicitation of individuals' expectations in survey questions as well as questions aimed at assessing whether an individual's condition is better than, equal to or worse than the condition of other colleagues performing the same task. Future research should also take into account a comparison between precrisis and post-crisis labour dynamics to test whether and how the economic crisis affected workers' perceptions of their working conditions. 


\section{References}

Alavinia, S. M., Molenaar, D., \& Burdorf, A. (2009). Productivity loss in the workforce: associations with health, work demands, and individual characteristics. American Journal of Industrial Medicine, 52(1), 49-56.

Askenazy, P., \& Caroli, E. (2010). Innovative work practices, information technologies, and working conditions: Evidence for France. Industrial Relations: A Journal of Economy and Society, 49(4), 544-565.

Barbieri, P., \& Scherer, S. (2009). Labour market flexibilization and its consequences in Italy. European Sociological Review, 25(6), 677-692.

Bardasi, E., \& Francesconi, M. (2004). The impact of atypical employment on individual wellbeing: evidence from a panel of British workers. Social Science \& Medicine, 58(9), 1671-1688.

Bartelsman, E., Scarpetta, S. \& Schivardi, F. (2003). Comparative analysis of firm demographics and survival: micro level evidence for the OECD countries. OECD Economic Department Working Paper, no. 348.

Bell, D. E. (1985). Disappointment in decision making under uncertainty. Operations Research, 33(1), 1-27.

Benavides, F. G., Benach, J., Diez-Roux, A. V., \& Roman, C. (2000). How do types of employment relate to health indicators? Findings from the Second European Survey on Working Conditions. Journal of Epidemiology and Community Health, 54(7), 494-501.

Bernhard-Oettel, C., Sverke, M., \& De Witte, H. (2005). Comparing three alternative types of employment with permanent full-time work: How do employment contract and perceived job conditions relate to health complaints? Work \& Stress, 19(4), 301-318.

Burchell, B., Cartron, D., Csizmadia, P., Delcampe, S., Gollac, M., Illéssy, M., Lorenz, E., Makó, C., O'Brien, C., \& Valeyre, A. (2009). Working conditions in the European Union: Working time and work intensity, Dublin: European Foundation for the Improvement of Living and Working Conditions.

Burchell, B., Sehnbruch, K., Piasna, A., \& Agloni, N. (2014). The quality of employment and decent work: definitions, methodologies, and ongoing debates, Cambridge Journal of Economics, 38, 459477.

Cahill, K. E., McNamara, T. K., Pitt-Catsouphes, M., \& Valcour, M. (2015). Linking shifts in the national economy with changes in job satisfaction, employee engagement and work-life balance. Journal of Behavioral and Experimental Economics, 56, 40-54.

Cioni, M., \& Savioli, M. (2016). Safety at the workplace: accidents and illnesses. Work, Employment \& Society, 30(5), 858-875. 
Clark, A. E. (1997). Job satisfaction and gender: why are women so happy at work? Labour Economics, 4(4), 341-372.

Clark, A. E., \& Etilé, F. (2011). Happy house: Spousal weight and individual well-being. Journal of Health Economics, 30(5), 1124-1136.

Clark, A. E., \& Oswald, A. J. (1996). Satisfaction and comparison income. Journal of Public Economics, 61(3), 359-381.

Clark, A., Oswald, A., \& Warr, P. (1996). Is job satisfaction U-shaped in age? Journal of Occupational and Organizational Psychology, 69(1), 57-81.

Cooper, C. L., Rout, U., \& Faragher, B. (1989). Mental health, job satisfaction, and job stress among general practitioners. British Medical Journal, 298(6670), 366-370.

Dolan, P., Peasgood, T., \& White, M. (2008). Do we really know what makes us happy? A review of the economic literature on the factors associated with subjective well-being. Journal of Economic Psychology, 29(1), 94-122.

Eurofound (2012), Fifth European Working Conditions Survey. Luxembourg: Publications Office of the European Union.

Felice, E. (2013). Perché il Sud è rimasto indietro. Bologna: il Mulino.

Felice, E. \& Vasta, M. (2015). Passive Modernization? Social Indicators and Human Development in Italy's Regions (1871-2009). European Review of Economic History, 19 (1), 44-66.

Fernandez, R. M., \& Nordman, C. J. (2009). Are there pecuniary compensations for working conditions? Labour Economics, 16(2), 194-207.

Fink, G., \& Masiye, F. (2015). Health and agricultural productivity: Evidence from Zambia. Journal of Health Economics, 42, 151-164.

García-Serrano, C. (2004). Temporary employment, working conditions and expected exits from firms. Labour, 18(2), 293-316.

Georgellis, Y., Lange, T., \& Tabvuma, V. (2012). The impact of life events on job satisfaction. Journal of Vocational Behavior, 80(2), 464-473.

Greene, W. H. (2007). Econometric Analysis. New Jersey: Prentice Hall.

Helliwell, J. F. \& Huang, H. (2011). Well-Being and Trust in the Workplace. Journal of Happiness Studies, 12, 747-767.

Hersch, J. (1991). Male-female differences in hourly wages: The role of human capital, working conditions, and housework. Industrial \& Labor Relations Review, 44(4), 746-759. 
Kahneman, D., \& Tversky, A. (1979). Prospect theory: An analysis of decision under risk. Econometrica: Journal of the Econometric Society, 47(2), 263-291.

Khanzode, V.V., Maiti J \& Ray, P.K. (2012). Occupational injury and accident research: A comprehensive review, Safety Science 50(5), 1355-1367.

Köszegi, B., \& Rabin, M. (2006). A model of reference-dependent preferences. The Quarterly Journal of Economics, 121(4), 1133-1165.

Loscocco, K. A., \& Spitze, G. (1990). Working conditions, social support, and the well-being of female and male factory workers. Journal of Health and Social Behavior, 31(4), 313-327.

Muñoz de Bustillo, R., \& Fernández-Macías, E. (2005). Job satisfaction as an indicator of the quality of work. The Journal of Socio-Economics, 34(5), 656-673.

Muñoz de Bustillo, R., Fernández-Macías, E., Antón, J. I., \& Esteve, F. (2011). Measuring More than Money. Cheltenham: Edward Elgar.

Papke, L. E., \& Wooldridge, J. (1993). Econometric methods for fractional response variables with an application to 401 (k) plan participation rates. Journal of Applied Econometrics, 11(6), 619-632.

Poggi, A. (2007). Do satisfactory working conditions contribute to explaining earning differentials in Italy? A panel data approach. Labour, 21(4-5), 713-733.

Poggi, A. (2010). Job satisfaction, working conditions and aspirations. Journal of Economic Psychology, 31(6), 936-949.

Robone, S., Jones, A. M., \& Rice, N. (2011). Contractual conditions, working conditions and their impact on health and well-being. The European Journal of Health Economics, 12(5), 429-444.

Rogers, S. J., \& May, D. C. (2003). Spillover Between Marital Quality and Job Satisfaction: LongTerm Patterns and Gender Differences. Journal of Marriage and Family, 65(2), 482-495.

Saloniemi, A., Virtanen, P., \& Vahtera, J. (2004). The work environment in fixed-term jobs: Are poor psychosocial conditions inevitable? Work, Employment and Society, 18(1), 193-208.

Schwandt, H. (2016). Unmet Aspirations as an Explanation for the Age U-shape in Wellbeing. Journal of Economic Behavior \& Organization, 122, 75-87.

Sloane, P. J., \& Williams, H. (2000). Job satisfaction, comparison earnings, and gender. Labour, 14(3), 473-502.

Sousa-Poza, A., \& Sousa-Poza, A. A. (2003). Gender differences in job satisfaction in Great Britain, 1991-2000: Permanent or transitory? Applied Economics Letters, 10(11), 691-694.

Travers, C. J., \& Cooper, C. L. (1993). Mental health, job satisfaction and occupational stress among UK teachers. Work \& Stress, 7(3), 203-219. 
Van Dijk, W. W., Zeelenberg, M., \& Van der Pligt, J. (2003). Blessed are those who expect nothing: Lowering expectations as a way of avoiding disappointment. Journal of Economic Psychology, 24(4), 505-516.

Zaleznik, A., Christensen, C. R., \& Roethlisberger F. J. (1958). The Motivation, Productivity, and Satisfaction of Workers: A Prediction Study. Harvard University.

\section{Appendix}

Table A1 - Variable definitions

Type

Definition

\begin{tabular}{|c|c|c|}
\hline \multicolumn{3}{|l|}{ Independent variables } \\
\hline \multicolumn{3}{|c|}{ Work characteristics } \\
\hline Full-time work & $\mathrm{D}$ & The worker has full-time work \\
\hline Overtime hours & $\mathrm{D}$ & The worker has overtime hours \\
\hline Shift work & $\mathrm{D}$ & The worker has shift work \\
\hline Place of work +10 & $\mathrm{D}$ & The place of work has more than ten workers \\
\hline Agriculture as the reference category & $\mathrm{D}$ & \multirow{5}{*}{ Sector of activity of the worker's firm } \\
\hline Industry excluding construction & $\mathrm{D}$ & \\
\hline Construction & $\mathrm{D}$ & \\
\hline Retail & $\mathrm{D}$ & \\
\hline Other activities & $\mathrm{D}$ & \\
\hline $\begin{array}{l}\text { Executive or entrepreneur as the reference } \\
\text { category }\end{array}$ & $\mathrm{D}$ & \multirow{8}{*}{$\begin{array}{r}\text { Specific kind of the worker's job } \\
\text { (occupation) }\end{array}$} \\
\hline Intellectual or scientific occupation & $\mathrm{D}$ & \\
\hline Technical position & $\mathrm{D}$ & \\
\hline Office clerk & $\mathrm{D}$ & \\
\hline Qualified occupation & $\mathrm{D}$ & \\
\hline Craftsman, skilled worker or farmer & $\mathrm{D}$ & \\
\hline Operator of industrial machinery & $\mathrm{D}$ & \\
\hline Unskilled occupation & $\mathrm{D}$ & \\
\hline \multicolumn{3}{|c|}{ Personal characteristics } \\
\hline Current job tenure & $\mathrm{N}$ & Months of the worker's current job tenure \\
\hline First job & $\mathrm{D}$ & The worker is new to the workforce \\
\hline Fixed-term contract & $\mathrm{D}$ & The worker has a fixed-term contract \\
\hline Female & $\mathrm{D}$ & The worker's gender is female \\
\hline Born in Italy & $\mathrm{D}$ & The worker's birthplace is in Italy \\
\hline Years of education & $\mathrm{N}$ & Years of education of the worker \\
\hline Educational activities in the last four weeks & $\mathrm{D}$ & $\begin{array}{r}\text { The worker had engaged in educational } \\
\text { activities in the four weeks preceding the } \\
\text { interview }\end{array}$ \\
\hline Age & $\mathrm{N}$ & Years of age of the worker \\
\hline Unemployment rate & $\mathrm{N}$ & Unemployment rate of the worker's region \\
\hline Unionization index & $\mathrm{I}$ & $\begin{array}{l}\text { \# workers registered to CGIL, CISL and UIL } \\
\text { at the regional level/employed population }\end{array}$ \\
\hline
\end{tabular}


(Istat) at the regional level

\begin{tabular}{|c|c|c|}
\hline Never married as the reference category & $\mathrm{D}$ & \\
\hline Married & $\mathrm{D}$ & \multirow{3}{*}{ Marital status of the worker } \\
\hline Separated or divorced & $\mathrm{D}$ & \\
\hline Widow/widower & $\mathrm{D}$ & \\
\hline \multicolumn{3}{|l|}{ Dependent variables } \\
\hline Bad working conditions & $\mathrm{I}$ & $\begin{array}{l}\text { Normalized (from } 0 \text { to } 1 \text { ) sum } \\
\text { of the indications of the risk factors }\end{array}$ \\
\hline Exposure to dust, fumes, chemicals & $\mathrm{D}$ & \multirow{4}{*}{ Risk factor } \\
\hline Noisy workplace & $\mathrm{D}$ & \\
\hline Bad posture induced by work & $\mathrm{D}$ & \\
\hline Feeling exposed to risk of injury & $\mathrm{D}$ & \\
\hline Bad physical working conditions & $\mathrm{I}$ & $\begin{array}{l}\text { Normalized (from } 0 \text { to } 1 \text { ) sum } \\
\text { of the indications of the first four risk factors }\end{array}$ \\
\hline Excessive workload & $\mathrm{D}$ & \multirow{3}{*}{ Risk factor } \\
\hline Feeling exposed to bullying or discrimination & $\mathrm{D}$ & \\
\hline Feeling exposed to threats or physical violence & $\mathrm{D}$ & \\
\hline Bad psychological working conditions & I & $\begin{array}{l}\text { Normalized (from } 0 \text { to } 1 \text { ) sum } \\
\text { of the indications of the last three risk factors }\end{array}$ \\
\hline
\end{tabular}

Note. Type: D dummy variable, $\mathrm{N}$ numerical variable, I index variable;

Data sources: 2007 Istat Labour Force Survey; "Conti economici regionali”, Istat. 


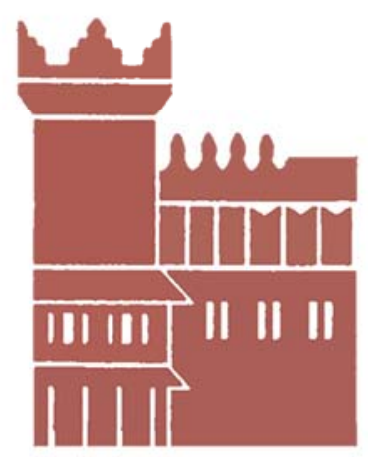

Alma Mater Studiorum - Università di Bologna DEPARTMENT OF ECONOMICS

Strada Maggiore 45

40125 Bologna - Italy

Tel. +39051 2092604

Fax +390512092664

http://www.dse.unibo.it 